\title{
\begin{tabular}{l|l} 
Mibraries & DSpace@MIT
\end{tabular}
}

\author{
MIT Open Access Articles
}

Techno-economic analysis of ion concentration polarization desalination for high salinity desalination applications

The MIT Faculty has made this article openly available. Please share how this access benefits you. Your story matters.

Citation: Choi, Siwon et al. "Techno-economic analysis of ion concentration polarization desalination for high salinity desalination applications." Water Research 155 (May 2019): 162-174 (c) 2019 Elsevier Ltd

As Published: http://dx.doi.org/10.1016/j.watres.2019.02.023

Publisher: Elsevier BV

Persistent URL: https://hdl.handle.net/1721.1/122631

Version: Author's final manuscript: final author's manuscript post peer review, without publisher's formatting or copy editing

Terms of use: Creative Commons Attribution-Noncommercial-Share Alike 


\section{Techno-economic Analysis of Ion Concentration Polarization Desalination for High Salinity Desalination Applications}

$18{ }^{1}$ These authors contributed equally in this work.

$19{ }^{+}$Current affiliation: Kongju National University, Cheonan, Chungcheongnam-do, Korea $20{ }^{*}$ Corresponding authors.

21 E-mail addresses : jyhan@mit.edu (J. Han), alanzi@mit.edu (B. Al-Anzi).

S. Choi, B. Kim, K.G. Nayar, J. Yoon, S. Alhammadi, J.H. Lienhard, J. Han, B. Al-Anzi, “Technoeconomic Analysis of Ion Concentration Polarization Desalination for High Salinity Desalination Applications," Water Research, online 25 February 2019, 155:162-174, 15 May 2019. https://doi.org/10.1016/j.watres.2019.02.023 


\section{Abstract}

23 A techno-economic analysis is used to evaluate the economic feasibility of ion concentration

24 polarization (ICP) desalination for seawater desalination and brine management. An empirical

25 optimization model based on a limited set of experimental data, which was obtained from a lab-

26 scale ICP desalination prototype, was established to calculate the required energy and membrane

27 area for a given set of operating parameters. By calculating operating and capital expenses in

28 various feed and product cases, the optimal levelized cost of water is determined over a range of

29 feed salinities, mostly above seawater salinity $(35 \mathrm{~g} / \mathrm{kg})$. Through these analyses, we study the

30 economic feasibility of three applications: 1) partial desalination of brine discharge by ICP (feed

31 varied from $35-75 \mathrm{~g} / \mathrm{kg})$ to common seawater RO feed level $(35 \mathrm{~g} / \mathrm{kg})$ in a hybrid ICP-RO system;

32 2) the concentration of seawater desalination brine for salt production, and 3) partial desalination

33 of oilfield wastewater. The economic feasibility of ICP desalination processes has been evaluated

34 and the rough cost of treatment has been generated for several relevant applications. The approach

35 taken in this work could be employed for other new and existing desalination processes, where $a$

36 priori process modeling and optimization is scientifically and/or numerically challenging.

\section{$39 \underline{\text { Keywords }}$}

40 Electromembrane desalination; high salinity desalination; brine management; economic analysis;

41 ion concentration polarization 


\section{Nomenclature}

$\begin{array}{lll}43 & \text { Roman symbols } & \\ 44 & A_{m} & \text { Total membrane area }\left(\mathrm{mm}^{2}\right) \\ C & \text { Concentration }(\mathrm{g} / \mathrm{kg}) \\ C E & \text { Current efficiency } \\ d & \text { ICP cell depth }(\mathrm{mm}) \\ F & \text { Faraday's constant }(=9.65 \times 104 \mathrm{C} / \mathrm{mol}) \\ I & \text { Electric current }(\mathrm{A}) \\ K_{E} & \text { Electricity rate }(\$ / \mathrm{kWh}) \\ K_{Q} & \text { Capital cost per unit membrane area }\left(\$ / \mathrm{m}^{2}\right) \\ L & \text { ICP cell length }(\mathrm{cm}) \\ Q & \text { Flowrate }(\mathrm{L} / \text { min) } \\ R & \text { Cost of capital }(\%) \\ S R R & \text { Salt removal ratio } \\ T & \text { Life time of equipment (year) } \\ V & \text { Voltage }(\mathrm{V}) \\ W & \text { ICP cell width }(\mathrm{mm})\end{array}$

45

46 Greek letters

47

$\mu \quad$ Dynamic viscosity $(\mathrm{g} /(\mathrm{cm} \cdot \mathrm{s}))$

48 


\section{Introduction}

50 Desalination processes for brackish water and seawater have greatly advanced over the past few

51 decades with the development of membrane desalination technologies. Reverse osmosis (RO), the

52 state-of-the-art membrane desalination technology, has reached an energy consumption $(\sim 3$

$\left.53 \mathrm{kWh} / \mathrm{m}^{3}\right)$ that is approaching the theoretical minimum $\left(\sim 1 \mathrm{kWh} / \mathrm{m}^{3}\right.$, for $35 \mathrm{~g} / \mathrm{kg}$ feed with $50 \%$

54 recovery) (Elimelech and Phillip, 2011; Lienhard et al., 2017) and electrodialysis, an

55 electromembrane desalination technology, has achieved $1.65 \sim 1.85 \mathrm{kWh} / \mathrm{m}^{3}$ (for $32 \sim 33 \mathrm{~g} / \mathrm{kg}$

56 feed) for seawater desalination(Aulick, 2014; "Bandwidth Study on Energy Use and Potential

57 Energy Savings Opportunities in U.S. Seawater Desalination Systems ,”2017). In spite of these

58 meaningful advances, desalination of high salinity brine, with salinity above seawater level (35

$59 \mathrm{~g} / \mathrm{kg}$ ), has been a continuing challenge with few economically attractive options for treatment. In

60 fact, the need for hypersaline brine desalination or concentration is growing, as the volume of brine

61 generation increases. Two major sources of the brine are the concentrate from seawater

62 desalination plants, and the wastewater (produced water) from modern oil / gas extraction

63 processes. With ever-increasing desalination capacity due to economic growth, the volume of brine

64 generation is steadily growing (Arnal et al., 2005; McGovern et al., 2013; Morillo et al., 2014).

65 Moreover, efficient desalination operation and higher recovery of pure product water have created

66 more concentrated brine $(50-85 \mathrm{~g} / \mathrm{kg})$ (Lattemann and Höpner, 2008), which makes treatment

67 more challenging. In the shale gas industry, management of produced water $(8-360 \mathrm{~g} / \mathrm{kg})$ is one

68 of the biggest challenges for economical and environmental reasons (Gregory et al., 2011; Shaffer

69 et al., 2013; Thiel et al., 2015; Vidic et al., 2013).

70 Current methods of brine management include surface discharge, solar evaporation, underground

71 injection, and internal reuse for enhanced oil recovery technologies (e.g. hydraulic fracturing). 
72 Surface discharge is the most rudimentary method of disposal with minimal costs involved.

73 However, the discharged brine can disrupt the ecosystem by increasing the local salinity of the

74 surface water and by contaminating the surface water with toxic chemicals added during

75 desalination or hydraulic fracturing (e.g., anti-foulants, anti-scalants, surfactants, etc.) (Del Bene

76 et al., 1994; Gacia et al., 2007; Roberts et al., 2010; Uddin et al., 2011). Solar evaporation involves

77 evaporating brine from large, shallow ponds using natural solar energy and removing residual solid

78 for disposal (Katzir et al., 2012). Evaporation ponds are easy to construct and to maintain, but

79 require large land footprint (which raises capital cost), and may cause environmental liabilities in

80 case of brine leakage (Ahmed et al., 2000; Gilron et al., 2003). Underground injection is the brine

81 management practice employed to dispose majority of produced water from shale gas operation

82 (Clark and Veil, 2009). Underground injection is limited by the number of available disposal wells

83 and the transportation from produced water generation sites to wells (Rassenfoss, 2011). To reduce

84 the brine volume in the shale gas industry, reuse of produced water has become increasingly

85 popular (Shaffer et al., 2013). Internal reuse of produced water can reduce the demand for injection

86 wells and freshwater, but can hurt the efficiency of the hydraulic fracturing process due to the high

87 concentration of dissolved ions and other chemicals (Lutz et al., 2013; Nicot and Scanlon, 2012).

88 Reuse needs to be accompanied by another disposal method, for the reused produce water will

89 eventually need to be disposed when the reuse demand becomes low as the shale gas formations

90 mature (Lutz et al., 2013; Shaffer et al., 2013; Vidic et al., 2013). As reviewed here, the current

91 brine management methods are not sustainable to treat an increasing volume of high salinity brine.

92 Therefore, desalination should be employed to reduce the volume of brine that needs to be

93 managed by solar evaporation or underground injection. 
94 Current desalination technologies for potential treatment of high salinity brine include reverse

95 osmosis, thermal desalination technologies, such as humidification-dehumidification (HDH)

96 multi-stage flash (MSF), multi-effect distillation (MED), and mechanical vapor compression

97 (MVC), and membrane distillation (MD) (Thiel et al., 2015). Techno-economic analyses have

98 been implemented to evaluate the economic benefits of technologies for desalination, water

99 treatment, and water reuse processes (Capocelli et al., 2019; Ghaffour et al., 2013; Prisciandaro et

100 al., 2016). Reverse osmosis (RO) is the most cost efficient desalination technology to treat saline

101 water with up to $35 \mathrm{~g} / \mathrm{kg}$ TDS (Fritzmann et al., 2007; Greenlee et al., 2009; Tow et al., 2015).

102 However, for high salinity feed, the RO membrane modules are not normally designed for the

103 hydraulic pressure needed to overcome the large osmotic pressure, which arises from the large

104 salinity difference between the feed and the permeate (Fritzmann et al., 2007; Greenlee et al.,

105 2009). For this reason, high salinity brine is typically treated with thermal technologies, such as

106 MVC, HDH, or MD (Chehayeb and Lienhard, 2015; Swaminathan et al., 2018). These thermal

107 desalination technologies are more energy intensive than membrane processes at any salinity, and

108 all technologies require greater energy input at higher salinities than at lower salinities (Thiel et

109 al., 2015). Further, many thermal technologies (such as MSF, MED, MVC) require large amounts

110 of costly metal heat transfer surfaces, resulting in relatively high investment cost and large

111 footprint, compared to membrane desalination (Darwish et al., 2003; Ghaffour et al., 2013); the

112 exception is HDH which achieves lower capex through use of inexpensive polymers. To obtain

113 low-temperature desalination plants of the MSF and MED type are typically built next to power

114 plants to utilize the heat generated from these plants, and thus these plants are less mobile and

115 scalable (Shaffer et al., 2013). MVC is a more scalable thermal desalination technology, with

116 electrical energy consumption in the range of $10-30 \mathrm{kWh} / \mathrm{m}^{3}$ for treatment of brine with salinity 
117 beyond seawater level (38 - $260 \mathrm{~g} / \mathrm{kg}$ ) (Chung et al., 2017; Koren and Nadav, 1994; Thiel et al.,

118 2015; Veza, 1995). MVC is modular in design, and thus involves lower capital cost and is built at

119 small scale more often than MSF and MED (Heins, 2010). Membrane distillation (MD) is a

120 relatively new technology and is a thermally driven membrane desalination process. Its advantages

121 are the use of low-grade heat source and the low sensitivity of performance to the feed salinity,

122 which makes the process appealing for high salinity brine treatment (Alkhudhiri et al., 2012;

123 Meindersma et al., 2006). Single stage MD with heat recovery can achieve thermal energy

124 consumption of $70-90 \mathrm{kWh} / \mathrm{m}^{3}$ for seawater desalination (ALOBAIDANI et al., 2008). MD has

125 also been proposed as the heat recovery element in MVC to improve its pure water recovery and

126 specific energy consumption (Swaminathan et al., 2016). Roughly speaking, the alternative

127 technologies for treating brine (salinity significantly higher than seawater) based on distillation

128 processes are priced around $\$ 20 \sim 50 / \mathrm{m}^{3}$, depending on the intake salinity and other parameters.

129 (Alkhudhiri et al., 2012; ALOBAIDANI et al., 2008; Meindersma et al., 2006)

130 Electromembrane desalination, such as electrodialysis (ED), exhibits characteristics that can be

131 particularly appealing for high salinity brine desalination. Since these processes are electrically

132 driven, highly saline water will increase the ion conductance, making the process more

133 energetically favorable (Chehayeb et al., 2017; Długołęcki et al., 2010). In addition,

134 electromembrane desalination enables 'partial desalination' because salt removal in the product

135 stream can be easily altered. Due to this reason, brine treatment by ED has been demonstrated in

136 several previous studies (Korngold et al., 2009; McGovern et al., 2014a; Nikonenko et al., 2014;

137 Oren et al., 2010; Strathmann, 2010; Turek, 2003). Ion concentration polarization (ICP)

138 desalination is an electromembrane desalination technology that has been developed by Han and

139 coworkers (Kim et al., 2016; Kwak et al., 2016). ICP desalination (Fig. 1a) is a unipolar 
140 electromembrane desalination process, employing one type of ion exchange membrane, whereas

141 ED employs both cation and anion exchange membranes. In the case that a feed stream has sodium

142 chloride as the majority salt, ICP desalination with cation exchange membrane (CEM)s can

143 remove salt (i.e., sodium chloride) more efficiently at a given current, because CEMs can generate

144 stronger depletion layer than AEMs due to the difference of diffusivity (the diffusivity of chloride

145 is higher than the diffusivity of sodium) (Kwak et al., 2016) (See Fig. 1(b)). The system was

146 engineered to operate more energy efficiently, and its potential application was identified to be in

147 partial desalination of high salinity brine (Kim et al., 2016; 2017).

148 In this work, we perform a more detailed techno-economic analysis to evaluate the economic

149 feasibility of ICP desalination for seawater desalination and desalination brine management. This

150 requires modeling prediction of efficiency at various flow rates and operating currents, for a given

151 brine intake. Yet, such a model-based optimization is not yet readily available for ICP desalination

152 nor electromembrane separation processes in general. While ICP desalination is utilizing the same

153 Cation Exchange Membranes (CEMs) as in ED, its unique fluidic and membrane architectures

154 prevent one from using widely accepted ED transport models. In addition, conventional ion

155 selective membranes (e.g. CEMs) are generally optimized for brackish desalination applications

156 (Strathmann, 2010), and it has been reported that high salinity intake water will generate many

157 nonlinearity in membrane performances, which are scientifically challenging to model accurately.

158 (Chehayeb and Lienhard, 2017; Narębska et al., 1984) In addition, it is often necessary to operate

159 electromembrane processes near limiting current (in order to get sufficient salt removal required

160 for brine treatment), for which there is no accurate transport models available. (Hattenbach and

161 Kneifel, 1986) 
162 Instead of a priori physics models, in this work we built an empirical model based on experimental

163 data from a lab scale prototype, to estimate the energy consumption and the membrane area for a

164 range of operating parameters that are relevant for brine desalination applications. Using this

165 model, we optimized the operating conditions for the minimum water cost, given the feed and the

166 product concentrations. We calculated the water cost for three applications: partial desalination of

167 brine to seawater level by ICP, followed by conventional RO; and concentration of seawater

168 desalination brine for salt production. The cost of water produced by ICP desalination was

169 compared with the cost of water produced by other desalination technologies to help determine the

170 competitiveness of ICP desalination.

\section{2. Methods}

\section{2.1. Experimental}

173 The experimental data was generated with a lab-scale ICP desalination device, whose

174 configuration, fabrication, and operation were described and demonstrated in a previous work

175 (Kim et al., 2017). The operation of ICP desalination is described in Fig. 1(a). The channel

176 dimensions were $2.5 \mathrm{~mm}$ in depth (i.e., effective intermembrane distance), $8 \mathrm{~mm}$ in effective width

177 (perpendicular to flow direction), and $30 \mathrm{~cm}$ in length (same as flow direction). The number of

178 unit flow cells is four, which means five CEMs were used in total. Two FTCM-E membranes

179 (FuMA-Tech GmbH, Germany), which is mechanically reinforced, are installed in the outside and

180 three Neosepta CMX membranes (Astom Co., Japan) are installed in the middle. The electric

181 potential drop for the unit cell is precisely measured by employing chloridized wired electrodes

$182(\mathrm{Ag} / \mathrm{AgCl}, \mathrm{A}-\mathrm{MSystems} \mathrm{Co}$., Sequim, WA) between the CEMs. This allows accurate measurement

183 of electric potential drop across single unit cell, without being affected by the large potential

184 variation occurring in the rinsing channel. A benchtop conductivity meter (Orion Star Series meter, 
185 Thermo Fisher Scientific Inc., Cambridge, MA) is connected to a flow-through conductivity

186 microelectrode (Microelectrode Inc., Bedford, $\mathrm{NH}$ ) in order to monitor real-time salinity changes.

187 The flow rate ratio of diluate to concentrate to feed stream was 1:1:2, and the overall recovery of

188 the diluate was $50 \%$. Varied parameters included feed salinity, flow velocity, and salt removal

189 ratio (SRR):

190

$$
S R R=\frac{C_{\text {feed }}-C_{\text {diluate }}}{C_{\text {feed }}}
$$

191 where $C_{\text {feed }}$ and $C_{\text {diluate }}$ are feed and product concentration, respectively. Since high salinity

192 desalination applications of ICP desalination were considered, the tested feed salinity ranged from

$19335 \mathrm{~g} / \mathrm{kg}$ to $100 \mathrm{~g} / \mathrm{kg}$ of sodium chloride. The ranges of salt removal and the flow velocity were

$19410 \%-90 \%$ and $0.25-3 \mathrm{~mm} / \mathrm{s}$, respectively. The current and voltage for each experiment were

195 consequently varied to achieve the target SRR for the given feed salinity and flow velocity.

196 2.2. Estimation of electrical energy consumption

197 In order to estimate electrical energy consumption for any given set of feed salinity, SRR, and flow

198 velocity, a relation must be built based on the experimental data. From the measured current and

199 voltage values, the power and the electrical energy consumption were calculated, and the relation

200 between the current and the power consumption were fitted to an equation. To estimate current for

201 a given set of feed salinity, SRR, and flow velocity, another fitting was done to first estimate

202 current efficiency (CE) as a function of SRR and flow velocity; the current efficiency was then

203 used to calculate the corresponding current. The relation between current and current efficiency is

204 shown in the equation below. 


$$
C E=\frac{z f Q_{\text {diluate }}\left(C_{\text {feed }}-C_{\text {diluate }}\right)}{I}
$$

206 where $\mathrm{z}$ is ion valence, $F$ is Faraday's constant, $Q_{\text {diluate }}$ is volumetric flowrate of product stream

207 and $I$ is total current.

\subsection{Levelized cost of water calculation}

209 The Levelized Cost of Water (LCOW) was calculated with a simple cost model that consists of

210 operating and capital costs. This method is a well-established method for cost analysis of

211 electrodialysis and ICP desalination (Kim et al., 2017; 2016; McGovern et al., 2014a; 2014b).

212 Electricity and pumping energies were used to calculate the operating cost. Total membrane area

213 was utilized to estimate the capital cost since the capital cost of electrodialysis, which is very

214 similar to ICP desalination in configuration and operation, depends strongly on the total membrane

215 area (Strathmann, 1992). Equations below were used to calculate the electricity, pumping, and

216 capital costs. The LCOW was obtained by summing the operating and capital costs and expressed

217 in US dollars per cubic meter of feed solution. Parameters used in the cost analysis are listed in

218 Table 1. The value of capital cost per unit membrane area $\left(K_{\mathrm{Q}}\right)$ was approximated with the $K_{\mathrm{Q}}$

219 values for ED and ICP desalination as guides (Kim et al., 2017; McGovern et al., 2014b; Sajtar

220 and Bagley, 2012). More specifically, the value of $K_{\mathrm{Q}}$ for ED were $\$ 480 / \mathrm{m}^{2}$-membrane in

221 McGovern et al. (McGovern et al., 2014b) and $\$ 600 / \mathrm{m}^{2}$-membrane from an industry quote (Nayar,

222 2016). ICP desalination presents the opportunity to reduce $K_{\mathrm{Q}}$ below that for ED desalination. ICP

223 desalination needs only CEM, but ED desalination requires both cation and anion exchange

224 membranes. The fouling in electromembrane processes mainly appears in the anion exchange

225 membrane depending on wastewater quality (Lee et al., 2009), because most organic foulants in 
226 many effluent streams are negatively charged, thus fouling anion exchange membranes due to

227 deposition and/or adsorption. Also, ICP desalination requires only two pumps for feed and rinse

228 streams, but ED desalination requires three pumps for the diluate, concentrate and rinse streams.

229 However, the value of $K_{\mathrm{Q}}$ for ICP desalination was assumed to be $25 \%$ higher than that for ED,

230 quoted from the industry $\left(\$ 600 / \mathrm{m}^{2}\right)$, since ICP desalination is a new technology, which requires

231 further development, and thus the manufacturing costs are higher. To obtain the optimal LCOW

232 for a given set of feed and product salinities, the LCOW was calculated over a range of flow

233 velocity (and resulting current), and the optimal operating conditions that result in the minimum

234 LCOW were determined.

$$
\begin{gathered}
\text { Electricity Cost }\left(\$ / \mathrm{m}^{3}\right)=\frac{I \times V}{Q} \times K_{\mathrm{E}}=\frac{P}{Q} \times K_{\mathrm{E}} \\
\text { Pumping Cost }\left(\$ / \mathrm{m}^{3}\right)=\frac{\text { Pumping Power }}{\text { Feed Flowrate per Cell }} \times N_{\text {cell }} \times K_{\mathrm{E}} \\
=\frac{12 \mu Q L}{w d^{3}} \times \frac{Q_{\text {total }}}{Q_{\text {cell }}} \times K_{\mathrm{E}} \\
\text { Capital Cost }\left(\$ / \mathrm{m}^{3}\right)=\frac{\text { Used Membrane Cost }(\$)}{\text { Output Flow Volume per Life }\left(\mathrm{m}^{3}\right)} \times \text { Anualized Factor } \\
=\frac{A_{\mathrm{m}} \times K_{\mathrm{Q}}}{Q \times T} \frac{(1+R)^{T}-1}{T \times R}
\end{gathered}
$$

\subsection{RO cost model}

237 The LCOW of reverse osmosis (RO) was calculated using a model and configuration that was

238 described in previous works (Mistry et al., 2011; Nayar et al., 2017; Thiel et al., 2015). The RO

239 configuration selected (shown in Fig. 2) was a conventional 1-stage arrangement with a circulation 
240 pump, a high pressure pump, a pressure exchanger and a booster pump. The RO model used

241 seawater thermophysical property correlations developed by Nayar et al. (Nayar et al., 2016) to

242 determine seawater osmotic pressure and density. The pinch pressure in the RO module (i.e., the

243 difference between hydraulic pressure and peak module osmotic pressure) was assumed to be 10

244 bar with a pressure loss of 2 bar assumed in the RO module. The pumps were assumed to have an

245 efficiency of 0.8 while the pressure exchanger was assumed to have an efficiency of 0.96 (Mistry

246 et al., 2011). The energy requirements were determined by basic equations for pump work,

247 described in Thiel et al. (Thiel et al., 2015) and Nayar et al. (Nayar et al., 2017). The capital cost

248 of the RO system was assumed to scale as $\$ 1206$ day $/ \mathrm{m}^{3}$ of RO water production (Nayar et al.,

249 2017). This value was an average value based on seawater RO plants from around the world,

250 sourced from DesalData (“Cost Estimator - DesalData (2017)," 2017). The capital cost was

251 annualized using the same factor described in Section 2.3.

\section{3. Results and discussion}

\section{3.1. Estimation of electrical energy consumption}

254 ICP desalination with high salinity brine (salinity $\geq 35 \mathrm{~g} / \mathrm{kg}$ ) was performed with a fixed device 255 configuration (i.e., fixed channel dimensions, cell numbers, and recovery ratio). Feed salinity, salt

256 removal ratio, and flow velocity were varied, and the resulting current and potential drop, from

257 which the power consumption was calculated, were measured. The power consumption was

258 plotted as a function of the applied current over a variety of operating parameters. The results show

259 a power-law relationship between the current and the power consumption (Fig. 3), which is

260 described by $y=0.416 x^{1.86}$ with $\mathrm{r}^{2}=0.985$, where $\mathrm{y}=P$ in Watts and $\mathrm{x}=I$ in amperes. The

261 fitting equation indicates that the relation is similar to the Ohm's law $\left(P=I^{2} R\right)$ with a constant

262 resistance $\mathrm{R}$ in the system. The total electrical resistance in the ICP desalination system includes 
263 contributions from the membrane, the bulk solution, the diffusion boundary layer, and the

264 electrical double layer (Długołęcki et al., 2010). At high salinity above seawater level, the solution

265 is highly conducting, so the membrane resistance becomes the main contributor to the total

266 resistance (Długołęcki et al., 2010). Therefore, the total resistance at high salinity is almost

267 constant because the membrane resistance sets a lower limit for the resistance.

268 To estimate the electrical energy consumption from the power relation, the current must be

269 calculated for the given operating conditions. The current is generally proportional to the rate of

270 ion removal, but we must consider the current efficiency (CE), which represents how much of the

271 total current is utilized for ion removal, as the $C E$ varies with operating conditions. The $C E$ trends

272 as a function of the salt removal ratio and flow velocity are shown in Fig. 4(a) and (b), respectively.

273 When other parameters are set constant, the $C E$ decreases with the salt removal ratio because

274 higher ion removal requires a higher current density and thus thicker ion depletion layers, which

275 cause undesirable phenomena, such as leakage of desalination, loss of membrane perm-selectivity

276 or water splitting, reducing the performance of ICP desalination (Fig. 1(b)) (Nayar et al., 2017).

277 The CE is a function of flow velocity, as well as the SRR, which is shown by the range of CE

278 values for the given SRR in Fig. 4(b). The $C E$ exhibits a quadratic relation with linear flow velocity

279 and peaks around $2 \mathrm{~mm} / \mathrm{s}$. This trend is a result of two effects: first, a high flow velocity reduces

280 the thickness of ion depletion layers and enhances the $C E$ (by minimizing the loss of depletion

281 region into the middle channel); second, a high flow velocity requires a high ion removal rate to

282 achieve the same salt removal ratio, leading to a high current density. High current density (high

$283 S R R$ ) are shown to precipitously decrease the $C E$, due to many non-ideal behaviors of

284 electromembrane separation (Luo et al., 2002; Yu et al., 2003). 
285 A similar result can be also found in other works(Długołęcki et al., 2009) that the concentration

286 polarization was greatly mitigated at flow velocity from 0 to $3 \mathrm{~mm} / \mathrm{s}$, but it was not much at flow

287 velocity higher than $3 \mathrm{~mm} / \mathrm{s}$. The combined effect of the salt removal ratio (or operating current)

288 and the flow velocity on the $C E$ was captured by a multivariate fitted model based on an extensive

289 set of experimental data operation membranes at various current and flow conditions. In Fig. 4(c),

290 the fitted model was plotted as a surface, and the experimental data were plotted as dots. Using

291 this model, we can estimate the $C E$ for a given combination of feed salinity, product salinity, and

292 flow velocity. The $C E$ was used to calculate the required current and the resulting power and

293 energy consumption. For feed salinity beyond $100 \mathrm{~g} / \mathrm{kg}$ (application $2 \& 3$, shown later) this model

294 for current efficiency is also applied to estimate the power consumption and corresponding total

295 cost by extending the current efficiency plot at salinity up to $200 \mathrm{~g} / \mathrm{kg}$. The accuracy of the current

296 estimation was evaluated by calculating the absolute percentage deviation (equation below) of the

297 estimated current from the measured current for the data set (Fig. 5). The average absolute

298 percentage deviation, defined as follows, was 9.5\%. This deviation mainly resulted from the

299 difference between of the fitted current efficiency and the actual current efficiency value. The CE

300 fitting model describes the general trend of $\mathrm{CE}$ as a function of the operating parameters described

301 above, but it becomes more challenging to estimate the exact $C E$ when more ions are involved

302 (i.e., higher SRR, concentration, and velocity), indicated by the larger deviation at higher current,

303 and when the concentration polarization effect is more significant.

$$
\text { Absolute percentage deviation }=\frac{\left|I_{\text {estimated }}-I_{\text {measured }}\right|}{I_{\text {measured }}} \times 100 \%
$$


306 The first application scenario of ICP desalination is partial desalination of high salinity brine to

307 the typical seawater level $(35 \mathrm{~g} / \mathrm{kg})$. Various sources of brine, or other feed waters, having salinities

308 higher than $35 \mathrm{~g} / \mathrm{kg}$ include: high salinity seawater in the Arabian Gulf (up to $50 \mathrm{~g} / \mathrm{kg}$ ), concentrate

309 from RO/MSF desalination plants (60 to $70 \mathrm{~g} / \mathrm{kg}$ ), and produced water from oil/gas extraction

310 processes (salinity widely varying with levels sometimes greater than $200 \mathrm{~g} / \mathrm{kg}$ ). As discussed in

311 the Introduction, only limited options exist for treatment of this brine. Here, we performed a cost

312 analysis to evaluate the economic feasibility of an ICP-RO hybrid system. ICP desalination is used

313 to bring down the salinity of a brine source to $35 \mathrm{~g} / \mathrm{kg}$, a level at which a follow-on reverse osmosis

314 system can operate efficiently. Based on the experimental data, the electrical energy was estimated

315 as described in Section 3.1, and the pumping energy was calculated to obtain the total energy

316 consumption. For a given set of the feed and product salinity, the flow velocity, and hence the

317 applied current, was varied to obtain the energy consumption as a function of the current density.

318 In Fig. 6(a), we show a case of partial desalination from the feed salinity of $50 \mathrm{~g} / \mathrm{kg}$ to a product

319 salinity of $35 \mathrm{~g} / \mathrm{kg}$. Fig. 6(b) shows a typical relation between the electrical and the pumping energy

320 and the current. A high current leads to a greater electrical power and energy consumption. It also

321 requires an increased flow and volumetric flowrate for the same salt removal ratio. Consequently,

322 the pumping energy increases with the current. However, the ICP desalination generally operates

323 with a low flow velocity, which is much slower than in electrodialysis, leading to very low pressure

324 drops and a negligible contribution of pumping power to the total energy consumption. The energy

325 consumption was used to calculate the operating cost; combined with the capital cost based on the

326 required membrane area, the LCOW is plotted as a function of the current density in Fig. 6(c). At

327 a fixed salt removal ratio, a high current result in a fast flow and reduces the membrane area

328 required, shown by the decreasing capital cost. Considering the contributions from the operating 
329 and the capital costs, the optimal current, electrical energy consumption, and LCOW were

330 determined to be $330 \mathrm{~A} / \mathrm{m}^{2}, 6.5 \mathrm{kWh} / \mathrm{m}^{3}$-ICP-diluate, and $\$ 1.4 / \mathrm{m}^{3}$-ICP-diluate, respectively.

331 We analyzed the LCOW of the partial desalination for a range of feed salinity and a fixed product 332 salinity of $35 \mathrm{~g} / \mathrm{kg}$ (Fig. 7). The LCOW increases with the feed salinity mainly because of the large 333 amount of ion removal required. For similar reasons, the optimal current density increases with

334 the feed salinity (Fig. 7(a)), as a high ion removal rate per membrane area is more cost efficient at 335 high salinity. Fig. 7(b) shows the breakdown of LCOW to the operating and the capital costs. As

336 the feed salinity increases, the operating cost accounts a greater portion of the LCOW due to the 337 increasing importance of high salt removal rate. For a feed salinity of $75 \mathrm{~g} / \mathrm{kg}$, the optimal electrical 338 energy consumption and the LCOW were $26 \mathrm{kWh} / \mathrm{m}^{3}$-ICP-diluate and $\$ 4.60 / \mathrm{m}^{3}$-ICP-diluate, 339 respectively. These values are similar to a comparable electrodialysis performance (feed and 340 product salinity of $90 \mathrm{~g} / \mathrm{kg}$ and $40.7 \mathrm{~g} / \mathrm{kg}$, respectively), which resulted in the electrical energy 341 consumption of $20-22 \mathrm{kWh} / \mathrm{m}^{3}$ of diluate stream and a LCOW of $\sim \$ 5.5 / \mathrm{m}^{3}$ of diluate stream 342 (McGovern et al., 2014a). Currently, complete treatment of high salinity brine can be done 343 efficiently via MVC technology. The MVC cost for shale gas produced water treatment is $\$ 22-$ $34439 / \mathrm{m}^{3}$ of product water (Slutz et al., 2012). Based on our cost analysis, the ICP partial desalination 345 in combination with reverse osmosis $\left(<\$ 2 / \mathrm{m}^{3}\right.$ of pure water) shows potential to be economically 346 competitive for high salinity produced water treatment when compared to the current MVC 347 technology.

348 Next, the LCOW from the ICP-RO hybrid process was analyzed. Here, partial desalination with 349 ICP desalination is followed by complete desalination (i.e., product salinity is $0 \mathrm{~g} / \mathrm{kg}$ ) with RO

350 (see Fig. 8(a)). The feed and the product salinities were fixed; the feed salinity to the RO step, or 351 the product salinity in the ICP desalination, was varied to determine the RO feed concentration for 
352 an optimal ICP-RO operation. The ICP recovery ratio was kept at $50 \%$, while the RO recovery

353 ratio was varied with the feed salinity to result in a concentrate stream concentration of $70 \mathrm{~g} / \mathrm{kg}$.

354 Fig. 8 shows the ICP-RO water cost for the starting salinity (i.e., the feed to the ICP-RO process)

355 of $50 \mathrm{~g} / \mathrm{kg}$ and $75 \mathrm{~g} / \mathrm{kg}$. The starting salinity of $50 \mathrm{~g} / \mathrm{kg}$ represents the highest seawater salinities

356 practically encountered in the northern parts of the Arabian Gulf while the choice of $75 \mathrm{~g} / \mathrm{kg}$

357 reflects a typical salinity of brine from seawater desalination plants. When the RO feed

358 concentration equals the starting salinity, the ICP desalination step was omitted, and the LCOW

359 was calculated for the sole RO treatment. Fig. 8(b) shows that the total water cost decreases with

360 a higher RO feed concentration and reaches a minimum for the solely RO operation. Generally, as

361 the RO feed concentration increases, the LCOW of RO increases, and the LCOW of ICP

362 desalination decreases. But in the case of $50 \mathrm{~g} / \mathrm{kg}$ feed, the RO cost is much smaller than the ICP

363 desalination cost for the entire range of the RO feed concentration, so the LCOW is minimized

364 when the ICP desalination is not used. Furthermore, when ICP desalination is used to pretreat the

365 RO feed with the ICP desalination recovery of $50 \%$, the total volume of desalinated water was

366 reduced to half, raising the water cost per volume of desalinated water. It has been shown that the

367 LCOW of ICP desalination increases with increasing recovery (Kim et al., 2016), while the LCOW

368 of RO should be independent of the ICP recovery. From our cost analysis, the RO-only

369 desalination is more efficient than the ICP-RO hybrid for feed salinity up to $50 \mathrm{~g} / \mathrm{kg}$. However,

370 practical seawater RO systems are used to treat feeds with salinities up to around $50 \mathrm{~g} / \mathrm{kg}$ with the

371 maximum operating pressure for the systems being around 68 bar, which corresponds to

372 concentrate side concentration of $73-74 \mathrm{~g} / \mathrm{kg}$ (Fritzmann et al., 2007). The maximum operating

373 pressure of conventional seawater RO is guided by concerns around water costs, efficiency and

374 membrane pressure limitations (Gottberg et al., 2017). The pressure limit in turn limit the brine 
375 and feed salinity levels. The recovery rate of the RO-only desalination can be achieved at $28.6 \%$

376 at the feed salinity of $50 \mathrm{~g} / \mathrm{kg}$, but ICP-RO hybrid can increase the recovery rate to $42.9 \%$. For

377 treating feed salinities greater than $50 \mathrm{~g} / \mathrm{kg}$, the ICP-RO hybrid can be a cost-efficient solution.

378 We analyzed the ICP-RO water cost for a starting salinity of $75 \mathrm{~g} / \mathrm{kg}$, which can represent a 379 concentrate stream from desalination seawater plants. As shown in Fig. 8(c), the water cost follows

380 a similar trend as in Fig. 8(b), but the minimum cost is obtained when the ICP/RO transition

381 concentration is $50 \mathrm{~g} / \mathrm{kg}$. This is because at a very high $\mathrm{RO}$ feed concentration, the RO recovery is

382 reduced drastically, hence greatly increasing the specific cost of both ICP and RO. The water cost

383 of $\$ 8-9$ per $\mathrm{m}^{3}$ of the pure product is much lower than the water cost of $\$ 22-39$ per $^{3}$ of product

384 water for MVC, which is the current technology for treating brine at this concentration. The 385 relatively low water cost of ICP-RO hybrid indicates that this technology may be an economically 386 viable method for treatment of brine at $75 \mathrm{~g} / \mathrm{kg}$.

\subsection{Application 2: Brine concentration for salt production}

388 The second application is the concentration of brine for salt production. In most brine management

389 practices, the diluate stream is considered the useful product. However, the concentrate stream can

390 also be a useful product. For salt production applications, the concentrated brine stream is fed in

391 to a crystallizer where salt is crystallized out (Turek, 2003). Crystallizers are expensive and so

392 typically, seawater is concentrated first using desalination technologies to reduce the load of the

393 crystallizer in salt production and reduce the overall cost (Chung et al., 2017). Chung et al. had

394 compared the performance of state-of-the-art crystallizers to state-of-the-art brine concentrators

395 and found that there was a greater scope for improving the energy efficiency of brine concentration

396 (Chung et al., 2017). This led us to investigate the potential of ICP desalination for use as brine

397 concentrator. 
398 Fig. 9(a) describes a multi-stage ICP desalination for brine concentration. The starting salinity of

$39970 \mathrm{~g} / \mathrm{kg}$ represents a typical brine concentration from seawater desalination plants, and the final

400 salinity of $200 \mathrm{~g} / \mathrm{kg}$ represents a typical feed to crystallizer in salt production plants. Since the ICP

401 desalination has a maximum recovery of $50 \%$, a single-stage ICP process can achieve a maximum

402 of two-fold concentration, and the concentration from $70 \mathrm{~g} / \mathrm{kg}$ to $200 \mathrm{~g} / \mathrm{kg}$ needs to be performed

403 in multiple stages. In the multi-stage ICP desalination scheme, the concentrate stream from each

404 stage is fed to the next stage for further concentration, with the recovery of $50 \%$ at each stage. The

405 LCOW is expressed as cost per final concentrate volume, and the optimized water cost will be

406 converted to cost per unit salt mass. In the three-stage ICP process shown in Fig. 9(b), the water

407 cost for a later stage is higher than the earlier stage because the later stage is working at a higher

408 concentration. The results in Fig. 9(c) show that the minimum water cost is obtained for the three-

409 stage system, which consists of the optimized number of stages. The addition of ICP stage has the

410 effect of lowering electricity cost for each stage, with the decrease in total electricity cost for the

411 system. The increase in stage number reduces the salt removal ratio for each stage, preventing the

412 ICP desalination from operating in a high current density condition, which causes inefficient salt

413 concentration. However, the capital cost increases with an increasing number of stages. The

414 optimal water cost is $\$ 21.7 / \mathrm{m}^{3}$, which corresponds to $\$ 95 /$ tonne salt produced. Adding the

415 crystallization cost of approximately $\$ 40 /$ tonne of salt(Nayar et al., 2017), the total salt production

416 cost from the ICP-crystallizer is $\$ 135 /$ tonne salt. The cost of brine concentration by multi-stage

417 ICP desalination is about twice of the brine concentration cost by electrodialysis (concentration

418 from $35 \mathrm{~g} / \mathrm{kg}$ to $200 \mathrm{~g} / \mathrm{kg}$ ), which is around $\$ 60 /$ tonne salt(Nayar et al., 2017). The large gap in the

419 cost from the two processes is most likely to stem from that the recovery in ICP desalination is

420 limited to $50 \%$ at each stage, whereas the recovery in ED is much higher. Furthermore, the ED 
421 cost is obtained from a working salt production plant, where the process is well engineered and

422 optimized, and thus the cost may be further lowered.

\section{$423 \quad 3.4$ Application 3 : Brine desalination for reuse}

424 The third application considered is the desalination of brine waste from the oil industry. The oil

425 industry generates highly concentrated brine waste, ranging from 100 to $200 \mathrm{~g} / \mathrm{kg}$ (Al-Shamari et

426 al., 2013; Arthur et al., 2005). Because of the high salinity, the brine waste is disposed through

427 underground injection or evaporation in a surface pit, with the potential for environment problems

428 (AlAnezi et al., 2013). Therefore, the concentration of brine should be reduced (via partial

429 desalination) to a level appropriate for disposal or reuse, or to the level amenable to other

430 desalination technologies (around seawater level).

431 The schematic illustration of multi-stage ICP desalination in Fig. 10(a) shows similar

432 configuration as the one shown in Fig. 9(a) for brine concentration. However, the brine

433 desalination utilizes the diluate stream as the inflow for the next stage. The final diluate salinities

434 for brine desalination are $10,25,40 \mathrm{~g} / \mathrm{kg}$, which represent salinity levels adequate for several reuse

435 scenarios, such as Enhanced Oil Recovery, Pressure-Retarded Osmosis (PRO, 25 g/kg) and RO

436 (40 g/kg), respectively (Huang et al., 2018; Piemonte et al., 2015; Royce et al., 1984; Shafer, 2011;

437 Shaffer et al., 2013). In order to find the minimum LCOW, we calculate every single water cost

438 with $1 \%$ SRR increment for the multi-stage desalination from 1-stage to 4-stage. The SRR for the

439 next stage is determined by the diluate salinity of the previous stage, while the final diluate salinity

440 is fixed. Fig. 10(b) and (c) indicate the LCOW changes in two-stage and three-stage ICP

441 desalination, respectively. Since the final diluate salinity determined by SRR of stage 2 (SRR-2),

442 the final diluate salinity decrease requires increase in 'SRR-2' which gives increase in operating

443 cost. The 'SRR-1' for the minimum LCOW increases with the final diluate salinity decrease. 
444 Increase in 'SRR-1' facilitates to reduce the LCOW for stage 2 as providing a lower salinity feed

445 water for stage 2, because higher salinity and 'SRR-2' cause loss of membrane permselectivity

446 and undesirable chemical reactions, resulting in poor energy efficiency. (Kim et al., 2016) As a

447 result, SRR-1 becomes a more dominant factor for a lower final diluate salinity. Fig. 10(d)

448 indicates the minimum LCOW for 10 (d-i), 25 (d-ii) and $40 \mathrm{~g} / \mathrm{kg}$ (d-iii) with various number of

449 stages in system. Most of the LCOW for multi-stage arises in the final stage because most of salt

450 is removed at the last stage. The total operating cost decreases slightly with increasing number of

451 stages; as explained in the salt production application (Section 3.3) an additional stage reduces the

452 energy consumption by distributing the energy load for salt removal to more stages. On the other

453 hand, the capital cost is usually lowest for the system with 1 or 2 stages and increases significantly

454 as the number of stages increases. The minimum LCOW is obtained for the two-stage system, $455 \$ 25.9, \$ 20.5$ and $\$ 16.4 / \mathrm{m}^{3}$ for 10,25 and $40 \mathrm{~g} / \mathrm{kg}$, respectively.

456 The brine treatment using multistage ICP has achieved a competitive cost $(\$ 16.4 \sim 25.9$

$457 \mathrm{~m}^{3}$ ) due to the cost flexibility associated with the salinity of the produced water compared to brine

458 treatment costs with current technologies. The brine treatment costs by current technologies are as

459 following : Multi-effect distillation or vapor compression distillation can obtain a pure water from

460 brine $(100 \sim 200 \mathrm{kppm})$ at a cost of about $\$ 19 \sim 31 / \mathrm{m}^{3}$ (Karapataki, 2010). Mechanical vapor

461 recompression can treat a brine with 80,000 to $240,000 \mathrm{mg} / \mathrm{L}$ at cost $\$ 22 \sim 39 / \mathrm{m}^{3}$ (Slutz et al.,

462 2012). The multistage batch-ED desalted the brine sequentially from $195 \mathrm{kppm}$ to $0.24 \mathrm{kppm}$ at a

463 cost of $\$ 29.35 / \mathrm{m}^{3}$ (McGovern et al., 2014a). The cost of a crystallizer for zero liquid discharge is

464 widely distributed from $\$ 0.66 / \mathrm{m}^{3}$ to $\$ 26.41 / \mathrm{m}^{3}$ depending on the feed salinity (Greenlee et al., 465 2009).

\section{4. Conclusions}


467 In this work, we utilized a set of experimental data from a lab-scale ICP desalination device to

468 build a model that estimates the electrical energy consumption of ICP desalination at high salinity.

469 This model was then used to calculate the operating cost, and the capital cost was calculated based

470 on the effective membrane area required to reach the throughput. For a fixed feed and product

471 salinity, the LCOW was calculated over a range of current, and the optimal operating conditions.

472 This LCOW analysis was performed for three potential applications of ICP desalination in high

473 salinity brine treatment.

474 The first application was partial desalination to seawater salinity $(35 \mathrm{~g} / \mathrm{kg})$ so that the product can

475 be treated by seawater reverse osmosis to make pure water. The cost analysis showed that the ICP

476 partial desalination cost with feed salinity of $75 \mathrm{~g} / \mathrm{kg}$ was comparable to electrodialysis

477 performance at similar feed and product salinity. This cost is much lower than the complete

478 desalination by MVC, a current desalination method for high-salinity produced water. Therefore,

479 brine treatment by ICP desalination in combination with seawater RO at seawater levels of feed

480 salinity can become an economically competitive option for high salinity brine desalination. The

481 cost analysis of an ICP-RO hybrid shows that for the feed salinity range, at which RO is normally

482 available, the ICP-RO hybrid is not economically feasible, mainly due to the reduced recovery in

483 ICP-RO. The RO cost was relatively insensitive to increasing feed salinity (over the range of $10-$

$48450 \mathrm{~g} / \mathrm{kg}$ ). However, the ICP-RO hybrid can be an economically viable solution for treatment of

485 brine from seawater desalination plants $(\sim 75 \mathrm{~g} / \mathrm{kg})$, which is at a concentration above the 486 operational limit of conventional seawater RO.

487 The second application considered the concentration of brine (to $200 \mathrm{~g} / \mathrm{kg}$ ) by a multi-stage ICP 488 process, for salt production. We varied the number of stages and found that the operation becomes 489 more efficient when the number of stages is minimized. The optimal three-stage system resulted 
490 in the LCOW of $\$ 135 /$ tonne salt produced. This cost is about twice the cost of brine concentration

491 by ED. The high ICP cost can be contributed to the large volume of treatment required in early

492 stages due to the ICP recovery limit of $50 \%$ per stage. To reduce the ICP cost for brine

493 concentration, the salt retention in the concentrate stream should be enhanced, and the distribution

494 of salt concentration (or salt removal) ratio at the stages can be optimized.

495 The third application was the desalination of brine (from $160 \mathrm{~g} / \mathrm{kg}$ ) by a multi-stage ICP process

496 for reuse of brine waste from the oil industry. We applied a similar multi-stage ICP process with

497 the second application, but the stream was sequentially desalinated. With the increase in the stage

498 number, an additional stage reduced the operating cost with reduction in energy consumption by

499 redistributing the energy load for salt removal. ICP desalination has the advantage of easily

500 enabling partial desalination, which is the feature shared by electrodialysis, obtaining $\$ 25.9, \$ 20.5$

501 and $\$ 16.4 / \mathrm{m}^{3}$ of the minimum LCOW to have 10,25 and $40 \mathrm{~g} / \mathrm{kg}$ of produced concentration,

502 respectively. Yet, compared with electrodialysis, ICP system has more flexibility in dealing with

503 fouling, since only more fouling-resistant CEMs can be utilized.

504 The concept of ICP desalination was introduced with microfluidic technology (Kwak et al., 2016),

505 and then lab-scale ICP desalination was developed to demonstrate applicability to industries

506 through increased throughput. In this paper, the economic feasibility of ICP desalination processes

507 have been assessed with three different brine treatment applications. The feature of partial

508 desalination by ICP desalination facilitates a variety of brine treatment scenarios, providing

509 minimized LCOW with the optimized stage number. However, ICP desalination still suffers from

510 a fixed recovery rate and a relatively high power consumption for brine treatment. In the future,

511 both experiments and modeling should be employed to improve the economic feasibility,

512 achieving better energy efficiency and improved the recovery rate. 


\section{Acknowledgements}

515 This work was supported by Kuwait Foundation for the Advancement of Sciences (KFAS) for 516 their financial support through Project No. P31475EC01. 


\section{Reference}

518 Ahmed, M., Shayya, W.H., Hoey, D., Mahendran, A., Morris, R., Al-Handaly, J., 2000. Use of evaporation ponds for brine disposal in desalination plants. Desalination 130, 155-168. doi:10.1016/S0011-9164(00)00083-7

Al-Shamari, A.R., Al-Mithin, A.W., Prakash, S., NACE, M.I., 2013. Some Empirical Observations about Bacteria Proliferation and Corrosion Damage Morphology in Kuwait Oilfield Waters, in:. Presented at the NACE CORROSION 2013, pp. 1-12.

AlAnezi, K., Belkharchouche, M., Alali, S., Abuhaimed, W., 2013. Produced water characterization in Kuwait and its impact on environment. Desalination and Water Treatment 51,302-306. doi:10.1080/19443994.2012.714524

Alkhudhiri, A., Darwish, N., Hilal, N., 2012. Membrane distillation: A comprehensive review. Desalination 287, 2-18. doi:10.1016/j.desal.2011.08.027

ALOBAIDANI, S., CURCIO, E., MACEDONIO, F., DIPROFIO, G., ALHINAI, H., DRIOLI, E., 2008. Potential of membrane distillation in seawater desalination: Thermal efficiency, sensitivity study and cost estimation. Journal of Membrane Science 323, 85-98. doi:10.1016/j.memsci.2008.06.006

Arnal, J.M., Sancho, M., Iborra, I., Gozálvez, J.M., Santafé, A., Lora, J., 2005. Concentration of brines from RO desalination plants by natural evaporation. Desalination 182, 435-439. doi:10.1016/j.desal.2005.02.036

Arthur, J.D., Langhus, B.G., Consulting, C.P.A., LLC, Tulsa, OK, 2005, 2005. Technical summary of oil \& gas produced water treatment technologies, ALL CONSULTING, LLC.

Aulick, R., 2014. Progress towards commercialization of a novel low-energy desalination system [WWW Document]. www.siww.com. URL http://archive.siww.com.sg/sites/default/files/DES_Mr-Rodney-Aulick.pdf (accessed 7.22.18).

Bandwidth Study on Energy Use and Potential Energy Savings Opportunities in U.S. Seawater Desalination Systems [WWW Document], 2017. Bandwidth Study on Energy Use and Potential Energy Savings Opportunities in U.S. Seawater Desalination Systems [WWW Document]. URL https://www.energy.gov/sites/prod/files/2017/12/f46/Seawater_desalination_bandwidth_stud y_2017.pdf (accessed 9.26.18).

Capocelli, M., Prisciandaro, M., Piemonte, V., Barba, D., 2019. A technical-economical approach to promote the water treatment \& reuse processes. Journal of Cleaner Production 207, 85-96. doi:10.1016/j.jclepro.2018.09.135

Chehayeb, K.M., Farhat, D.M., Nayar, K.G., Lienhard, J.H., 2017. Optimal design and operation of electrodialysis for brackish-water desalination and for high-salinity brine concentration. Desalination 420, 167-182. doi:10.1016/j.desal.2017.07.003

Chehayeb, K.M., Lienhard, J.H., 2017. Entropy generation analysis of electrodialysis. Desalination 413, 184-198. doi:10.1016/j.desal.2017.03.001

Chehayeb, K.M., Lienhard, J.H., 2015. Effect of feed salinity on the performance of humidification dehumidification desalination, in:. Presented at the IDA World Congress on Desalination and Water Reuse, San Diego, pp. 1-17.

Chung, H.W., Nayar, K.G., Swaminathan, J., Chehayeb, K.M., Lienhard, J.H., 2017. Thermodynamic analysis of brine management methods: Zero-discharge desalination and salinity-gradient power production. Desalination 404, 291-303. doi:10.1016/j.desal.2016.11.022 
Clark, C.E., Veil, J.A., 2009. Produced water volumes and management practices in the United States. (No. ANL/EVS/R-09-1), Argonne National Lab. Argonne, IL (United States). doi:10.2172/1007397

Cost Estimator - DesalData (2017) [WWW Document], 2017. Cost Estimator - DesalData (2017) [WWW Document]. desaldata.com. URL https://www.desaldata.com/cost_estimator (accessed 17).

Darwish, M.A., Asfour, Al, F., Al-Najem, N., 2003. Energy consumption in equivalent work by different desalting methods: case study for Kuwait. Desalination 152, 83-92. doi:10.1016/S0011-9164(02)01051-2

Del Bene, J.V., Jirka, G., Largier, J., 1994. Ocean brine disposal. Desalination 97, 365-372. doi:10.1016/0011-9164(94)00100-6

Długołęcki, P., Gambier, A., Nijmeijer, K., Wessling, M., 2009. Practical Potential of Reverse Electrodialysis As Process for Sustainable Energy Generation. Environ Sci Technol 43, 6888-6894. doi:10.1021/es9009635

Długołęcki, P., Ogonowski, P., Metz, S.J., Saakes, M., Nijmeijer, K., Wessling, M., 2010. On the resistances of membrane, diffusion boundary layer and double layer in ion exchange membrane transport. Journal of Membrane Science 349, 369-379. doi:10.1016/j.memsci.2009.11.069

Elimelech, M., Phillip, W.A., 2011. The Future of Seawater Desalination: Energy, Technology, and the Environment. Science 333, 712-717. doi:10.1126/science.1200488

Fritzmann, C., Löwenberg, J., Wintgens, T., Melin, T., 2007. State-of-the-art of reverse osmosis desalination. Desalination 216, 1-76. doi:10.1016/j.desal.2006.12.009

Gacia, E., Invers, O., Manzanera, M., Ballesteros, E., Romero, J., 2007. Impact of the brine from a desalination plant on a shallow seagrass (Posidonia oceanica) meadow. Estuarine, Coastal and Shelf Science 72, 579-590. doi:10.1016/j.ecss.2006.11.021

Ghaffour, N., Missimer, T.M., Amy, G.L., 2013. Technical review and evaluation of the economics of water desalination: Current and future challenges for better water supply sustainability. Desalination 309, 197-207. doi:10.1016/j.desal.2012.10.015

Gilron, J., Folkman, Y., Savliev, R., Waisman, M., Kedem, O., 2003. WAIV - wind aided intensified evaporation for reduction of desalination brine volume. Desalination 158, 205214. doi:10.1016/S0011-9164(03)00453-3

Gottberg, von, A., Pang, A., Talavera, J.L., 2017. optimizing water recovery and energy consumption for seawater RO systems.

Greenlee, L.F., Lawler, D.F., Freeman, B.D., Marrot, B., Moulin, P., 2009. Reverse osmosis desalination: Water sources, technology, and today's challenges. Water Research 43, 2317 2348. doi:10.1016/j.watres.2009.03.010

Gregory, K.B., Vidic, R.D., Dzombak, D.A., 2011. Water Management Challenges Associated with the Production of Shale Gas by Hydraulic Fracturing. Elements 7, 181-186. doi:10.2113/gselements.7.3.181

Hattenbach, K., Kneifel, K., 1986. The effect of cell thickness and flow velocity on water cost in desalination by electrodialysis. Desalination 58, 33-41. doi:10.1016/0011-9164(86)85010-X

Heins, W.F., 2010. Is a Paradigm Shift in Produced Water Treatment Technology Occurring at SAGD Facilities? Journal of Canadian Petroleum Technology 49, 10-15. doi:10.2118/132804-PA 
Huang, F.Y.C., Martinez, A.D., Wei, Q., 2018. Beneficial Use of Highly Saline Produced Water in Pressure-Retarded Osmosis. Environmental Engineering Science 35, 472-483. doi:10.1089/ees.2017.0234

Karapataki, C., 2010. Techno-economic analysis of water management options for unconventional natural gas developments in the Marcellus Shale. Massachusetts Institute of Technology.

Katzir, L., Volkmann, Y., Daltrophe, N., Korngold, E., Mesalem, R., Oren, Y., Gilron, J., 2012. WAIV - Wind aided intensified evaporation for brine volume reduction and generating mineral byproducts. Desalination and Water Treatment 13, 63-73. doi:10.5004/dwt.2010.772

Kim, B., Kwak, R., Kwon, H.J., Van Sang Pham, Kim, M., Al-Anzi, B., Lim, G., Han, J., 2016. Purification of High Salinity Brine by Multi-Stage Ion Concentration Polarization Desalination. Sci Rep 6, 31850. doi:10.1038/srep31850

Kim, B., Kwon, H., Ko, S.H., Lim, G., Han, J., 2017. Partial desalination of hypersaline brine by lab-scale ion concentration polarization device. Desalination 412, 20-31. doi:10.1016/j.desal.2017.02.018

Koren, A., Nadav, N., 1994. Mechanical vapour compression to treat oil field produced water. Desalination 98, 41-48. doi:10.1016/0011-9164(94)00130-8

Korngold, E., Aronov, L., Daltrophe, N., 2009. Electrodialysis of brine solutions discharged from an RO plant. Desalination 242, 215-227. doi:10.1016/j.desal.2008.04.008

Kwak, R., Pham, V.S., Kim, B., Chen, L., Han, J., 2016. Enhanced Salt Removal by Unipolar Ion Conduction in Ion Concentration Polarization Desalination. Sci Rep 6, 25349. doi:10.1038/srep25349

Lattemann, S., Höpner, T., 2008. Environmental impact and impact assessment of seawater desalination. Desalination 220, 1-15. doi:10.1016/j.desal.2007.03.009

Lee, H.-J., Hong, M.-K., Han, S.-D., Cho, S.-H., Moon, S.-H., 2009. Fouling of an anion exchange membrane in the electrodialysis desalination process in the presence of organic foulants. Desalination 238, 60-69. doi:10.1016/j.desal.2008.01.036

Lienhard, J.H., Mistry, K.H., Sharqawy, M.H., Thiel, G.P., 2017. Thermodynamics, Exergy, and Energy Efficiency in Desalination Systems. Desalination Sustainability 127-206. doi:10.1016/b978-0-12-809791-5.00004-3

Luo, G.S., Pan, S., Liu, J.G., 2002. Use of the electrodialysis process to concentrate a formic acid solution. Desalination 150, 227-234. doi:10.1016/S0011-9164(02)00978-5

Lutz, B.D., Lewis, A.N., Doyle, M.W., 2013. Generation, transport, and disposal of wastewater associated with Marcellus Shale gas development. Water Resources Research 49, 647-656. doi:10.1002/wrcr.20096

McGovern, R.K., Weiner, A.M., Sun, L., Chambers, C.G., Zubair, S.M., Lienhard, J.H., 2014a. On the cost of electrodialysis for the desalination of high salinity feeds. Applied Energy 136, 649-661. doi:10.1016/j.apenergy.2014.09.050

McGovern, R.K., Zubair, S.M., Lienhard, J.H., 2014b. The benefits of hybridising electrodialysis with reverse osmosis. Journal of Membrane Science 469, 326-335. doi:10.1016/j.memsci.2014.06.040

McGovern, R.K., Zubair, S.M., Lienhard, J.H., 2013. Design and optimization of hybrid ED-RO system for the treatment of highly saline brines, in:. Presented at the The International Desalination Association World Congress on Desalination and Water Reuse, Tianjin, China. 
652

653

654

655

656

657

658

659

660

661

662

663

664

665

666

667

668

669

670

671

672

673

674

675

676

677

678

679

680

681

682

683

684

685

686

687

688

689

690

691

692

693

694

695

696

697

Meindersma, G.W., Guijt, C.M., de Haan, A.B., 2006. Desalination and water recycling by air gap membrane distillation. Desalination 187, 291-301. doi:10.1016/j.desal.2005.04.088

Mistry, K.H., McGovern, R.K., Thiel, G.P., Summers, E.K., Zubair, S.M., Lienhard, J.H., 2011. Entropy Generation Analysis of Desalination Technologies. Entropy 2011, Vol. 13, Pages 1829-1864 13, 1829-1864. doi:10.3390/e13101829

Morillo, J., Usero, J., Rosado, D., Bakouri, El, H., Riaza, A., Bernaola, F.-J., 2014. Comparative study of brine management technologies for desalination plants. Desalination 336, 32-49. doi:10.1016/j.desal.2013.12.038

Narębska, A., Koter, S., Kujawski, W., 1984. Ions and water transport across charged nafion membranes. Irreversible thermodynamics approach. Desalination 51, 3-17. doi:10.1016/0011-9164(84)85048-1

Nayar, K.G., 2016. Personal Communication, Asahi Glass and Chemicals Co.

Nayar, K.G., Fernandes, J., McGovern, R.K., Dominguez, K., Al-Anzi, B., Lienhard, J.H., 2017. Costs and Energy Needs of RO-ED Hybrid Systems for Zero Brine Discharge Seawater Desalination, in:. Int. Desalin. Assoc. World Congr. 2017, Sao Paulo, Brazil.

Nayar, K.G., Fernandes, J., McGovern, R.K., Dominguez, K.P., McCance, A., Al-Anzi, B., Lienhard, J.H., 2019. Cost and energy requirements of hybrid RO and ED brine concentration systems for salt production. Desalination (accepted).

Nayar, K.G., Sharqawy, M.H., Banchik, L.D., Lienhard, J.H., 2016. Thermophysical properties of seawater: A review and new correlations that include pressure dependence. Desalination 390, 1-24. doi:10.1016/j.desal.2016.02.024

Nicot, J.-P., Scanlon, B.R., 2012. Water Use for Shale-Gas Production in Texas, U.S. Environ Sci Technol 46, 3580-3586. doi:10.1021/es204602t

Nikonenko, V.V., Kovalenko, A.V., Urtenov, M.K., Pismenskaya, N.D., Han, J., Sistat, P., Pourcelly, G., 2014. Desalination at overlimiting currents: State-of-the-art and perspectives. Desalination 342, 85-106. doi:10.1016/j.desal.2014.01.008

Oren, Y., Korngold, E., Daltrophe, N., Messalem, R., Volkman, Y., Aronov, L., Weismann, M., Bouriakov, N., Glueckstern, P., Gilron, J., 2010. Pilot studies on high recovery BWRO-EDR for near zero liquid discharge approach. Desalination 261, 321-330. doi:10.1016/j.desal.2010.06.010

Piemonte, V., Prisciandaro, M., Di Paola, L., Barba, D., 2015. Membrane processes for the treatment of produced waters, CHEMICAL ENGINEERING TRANSACTIONS. doi:10.3303/CET1543384

Prisciandaro, M., Capocelli, M., Piemonte, V., Barba, D., 2016. Process analysis applied to water reuse for a "closed water cycle" approach. Chem. Eng. J. 304, 602-608. doi:10.1016/j.cej.2016.06.134

Rassenfoss, S., 2011. From Flowback to Fracturing: Water Recycling Grows in the Marcellus Shale. Journal of Petroleum Technology 63, 48-51. doi:10.2118/0711-0048-JPT

Roberts, D.A., Johnston, E.L., Knott, N.A., 2010. Impacts of desalination plant discharges on the marine environment: A critical review of published studies. Water Research 44, 5117-5128. doi:10.1016/j.watres.2010.04.036

Royce, B., Kaplan, E., Garrell, M., Geffen, T.M., 1984. Enhanced oil recovery water requirements. Minerals and the Environment 6, 44-53. doi:10.1007/BF02072654

Sajtar, E.T., Bagley, D.M., 2012. Electrodialysis reversal: Process and cost approximations for treating coal-bed methane waters. Desalination and Water Treatment 2, 284-294. doi:10.5004/dwt.2009.259 
Shafer, L., 2011. Water Recycling and Purification in the Pinedale Anticline Field: Results From the Anticline Disposal Project, in.. Presented at the SPE Americas E\&P Health, Safety, Security, and Environmental Conference, Society of Petroleum Engineers. doi:10.2118/141448-MS

Shaffer, D.L., Arias Chavez, L.H., Ben-Sasson, M., Romero-Vargas Castrillón, S., Yip, N.Y., Elimelech, M., 2013. Desalination and Reuse of High-Salinity Shale Gas Produced Water: Drivers, Technologies, and Future Directions. Environ Sci Technol 47, 9569-9583. doi:10.1021/es401966e

Slutz, J.A., Anderson, J.A., Broderick, R., Horner, P.H., 2012. Key Shale Gas Water Management Strategies: An Economic Assessment, International Conference on Health, Safety and Environment in Oil and Gas Exploration and Production. Society of Petroleum Engineers. doi:10.2118/157532-MS

Strathmann, H., 2010. Electrodialysis, a mature technology with a multitude of new applications. Desalination 264, 268-288. doi:10.1016/j.desal.2010.04.069

Strathmann, H., 1992. Design and Cost Estimates, in: Membrane Handbook. Springer, Boston, MA, Boston, MA, pp. 246-254. doi:10.1007/978-1-4615-3548-5_19

Swaminathan, J., Chung, H.W., Warsinger, D.M., Lienhard, J.H., 2018. Energy efficiency of membrane distillation up to high salinity: Evaluating critical system size and optimal membrane thickness. Applied Energy 211, 715-734. doi:10.1016/j.apenergy.2017.11.043

Swaminathan, J., Nayar, K.G., Lienhard, J.H., 2016. Mechanical vapor compressionMembrane distillation hybrids for reduced specific energy consumption. Desalination and Water Treatment 57, 26507-26517. doi:10.1080/19443994.2016.1168579

Thiel, G.P., Tow, E.W., Banchik, L.D., Chung, H.W., Lienhard, J.H., 2015. Energy consumption in desalinating produced water from shale oil and gas extraction. Desalination 366, 94-112. doi:10.1016/j.desal.2014.12.038

Tow, E.W., McGovern, R.K., Lienhard, J.H., 2015. Raising forward osmosis brine concentration efficiency through flow rate optimization. Desalination 366, 71-79. doi:10.1016/j.desal.2014.10.034

Turek, M., 2003. Dual-purpose desalination-salt production electrodialysis. Desalination 153, 377-381. doi:10.1016/S0011-9164(02)01131-1

Uddin, S., Ghadban, Al, A.N., Khabbaz, A., 2011. Localized hyper saline waters in Arabian Gulf from desalination activity - an example from South Kuwait. Environ Monit Assess 181, 587-594. doi:10.1007/s10661-010-1853-1

Veza, J., 1995. Mechanical vapour compression desalination plants - A case study. Desalination 101, 1-10. doi:10.1016/0011-9164(95)00002-J

Vidic, R.D., Brantley, S.L., Vandenbossche, J.M., Yoxtheimer, D., Abad, J.D., 2013. Impact of Shale Gas Development on Regional Water Quality. Science 340, 1235009-1235009. doi:10.1126/science. 1235009

Yu, L., Lin, T., Guo, Q., Hao, J., 2003. Relation between mass transfer and operation parameters in the electrodialysis recovery of acetic acid. Desalination 154, 147-152. doi:10.1016/S0011-9164(03)80015-2 
739 Table 1. Variables and parameters for cost analysis

\begin{tabular}{|c|c|c|c|}
\hline Symbol & Description & Value & Unit \\
\hline I & Current & & $\overline{\mathrm{A}}$ \\
\hline $\mathrm{V}$ & Voltage & & $\mathrm{V}$ \\
\hline $\mathrm{Q}$ & Feed flowrate & & $\mathrm{L} / \mathrm{min}$ \\
\hline $\mathrm{K}_{\mathrm{E}}$ & Electricity rate & 0.1 & $\$ / \mathrm{kWh}$ \\
\hline$\mu$ & Dynamic viscosity & 0.00972 & $\mathrm{~g} /(\mathrm{cm} \cdot \mathrm{s})$ \\
\hline $\mathrm{L}$ & Cell length & 30 & $\mathrm{~cm}$ \\
\hline $\mathrm{w}$ & Cell width (effective) & 8 & $\mathrm{~mm}$ \\
\hline $\mathrm{d}$ & Cell depth (i.e., intermembrane distance) & 2.5 & $\mathrm{~mm}$ \\
\hline Qtotal & Total flowrate & & $\mathrm{L} / \mathrm{min}$ \\
\hline $\mathrm{Q}_{\text {cell }}$ & Flowrate per cell & & $\mathrm{L} / \mathrm{min}$ \\
\hline $\mathrm{A}_{\mathrm{m}}$ & Total membrane area & & $\mathrm{m}^{2}$ \\
\hline $\mathrm{K}_{\mathrm{Q}}$ & Capital cost per unit membrane area & 750 & $\$ / \mathrm{m}^{2}$ \\
\hline $\mathrm{R}$ & Cost of capital & 10 & $\%$ \\
\hline $\mathrm{T}$ & Life time of equipment & 20 & year \\
\hline
\end{tabular}


(a)

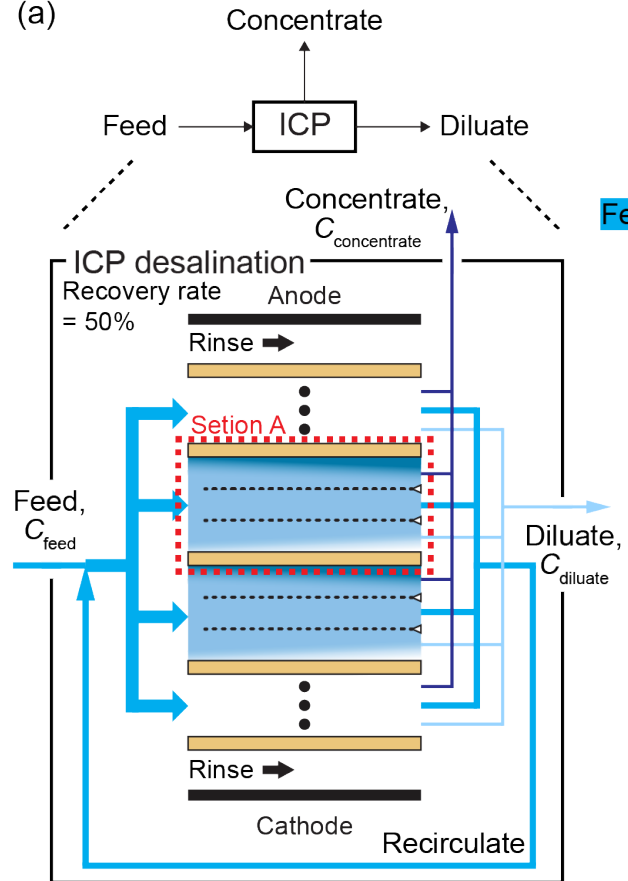

(b-i) Section A for low current density

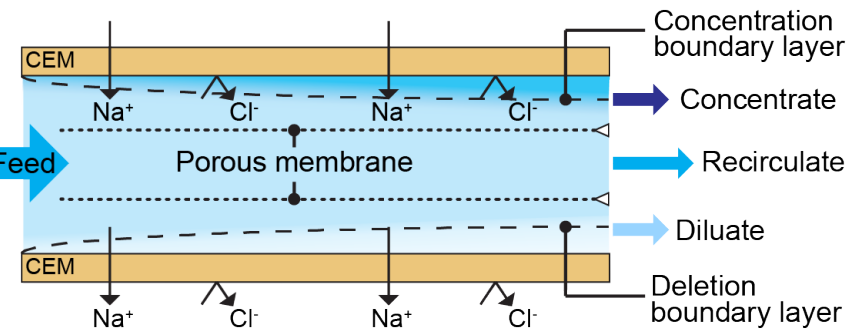

(b-ii) Section A for high current density

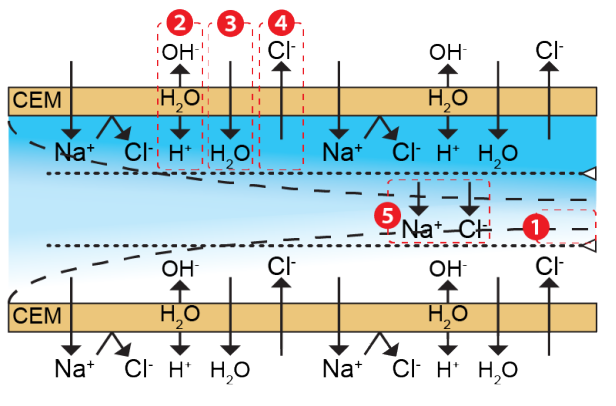

(1) Leakage of depleted region 2 Loss of permselectivity 3 Water splitting (4) Osmotic water transport (5) Back-diffusion

Fig. 1 (a) Schematic illustration of ICP desalination. Descriptions of ion movement (solid lines) and flow stream lines (dashed lines) under (b-i) low and (b-ii) high current density. 


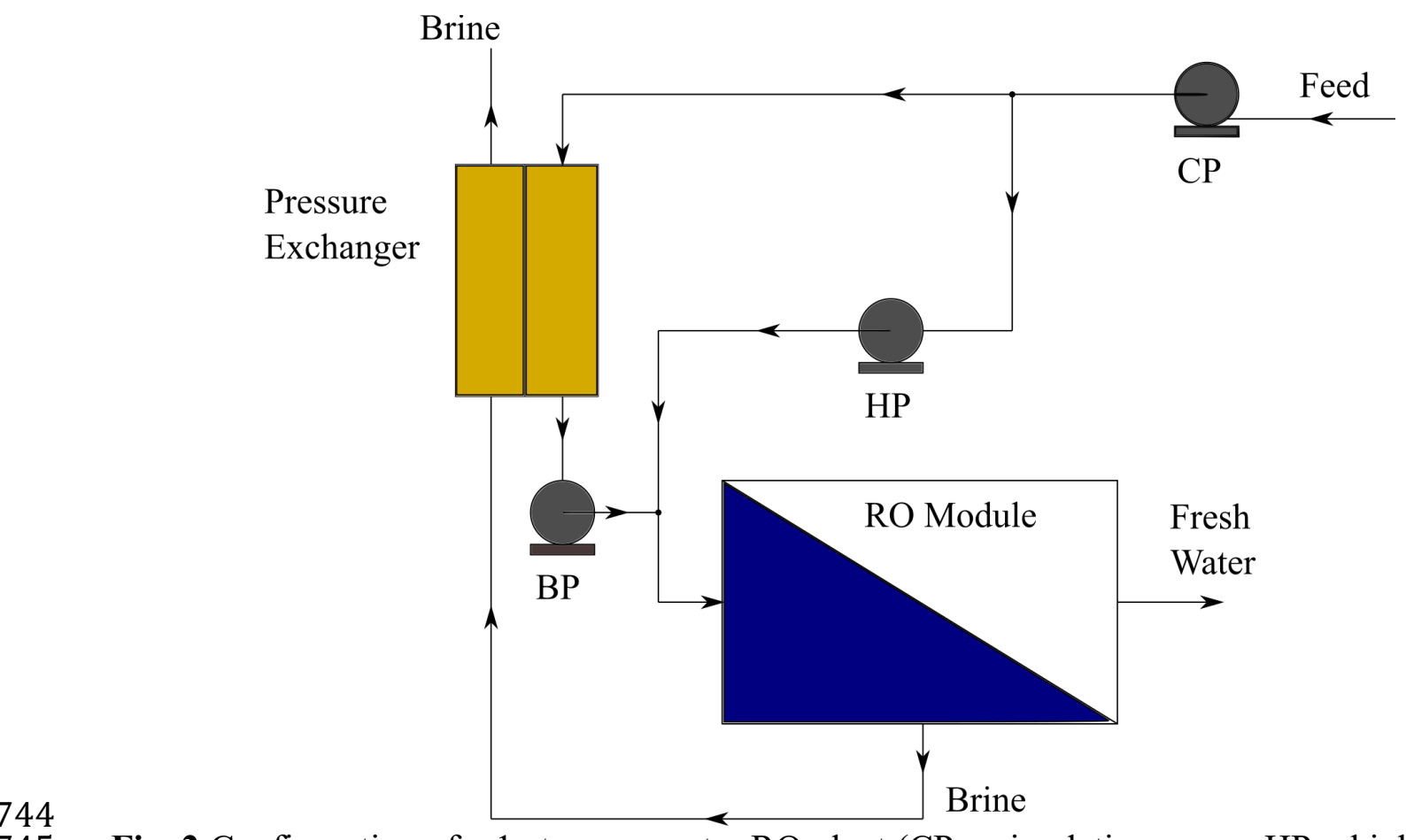

745 Fig. 2 Configuration of a 1-stage seawater RO plant (CP - circulation pump, HP - high pressure 746 pump and BP - booster pump) 


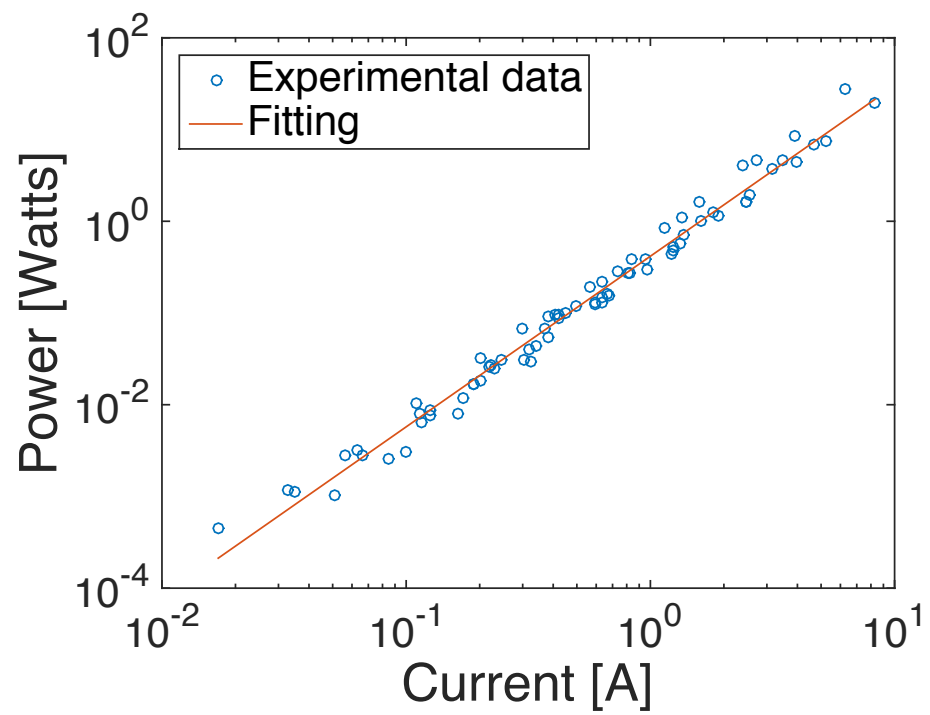

748 Fig. 3 Power relation between power consumption and applied current in ICP desalination. The

749 experimental data were generated with a fixed device configuration over various parameters (e.g., 750 feed salinity, salt removal ratio, and flow velocity). The fitted equation is in the form of $\mathrm{P}=\mathrm{a} \times \mathrm{I}^{\mathrm{b}}$ 751 where $\mathrm{P}$ and I are power consumption and current, respectively. 

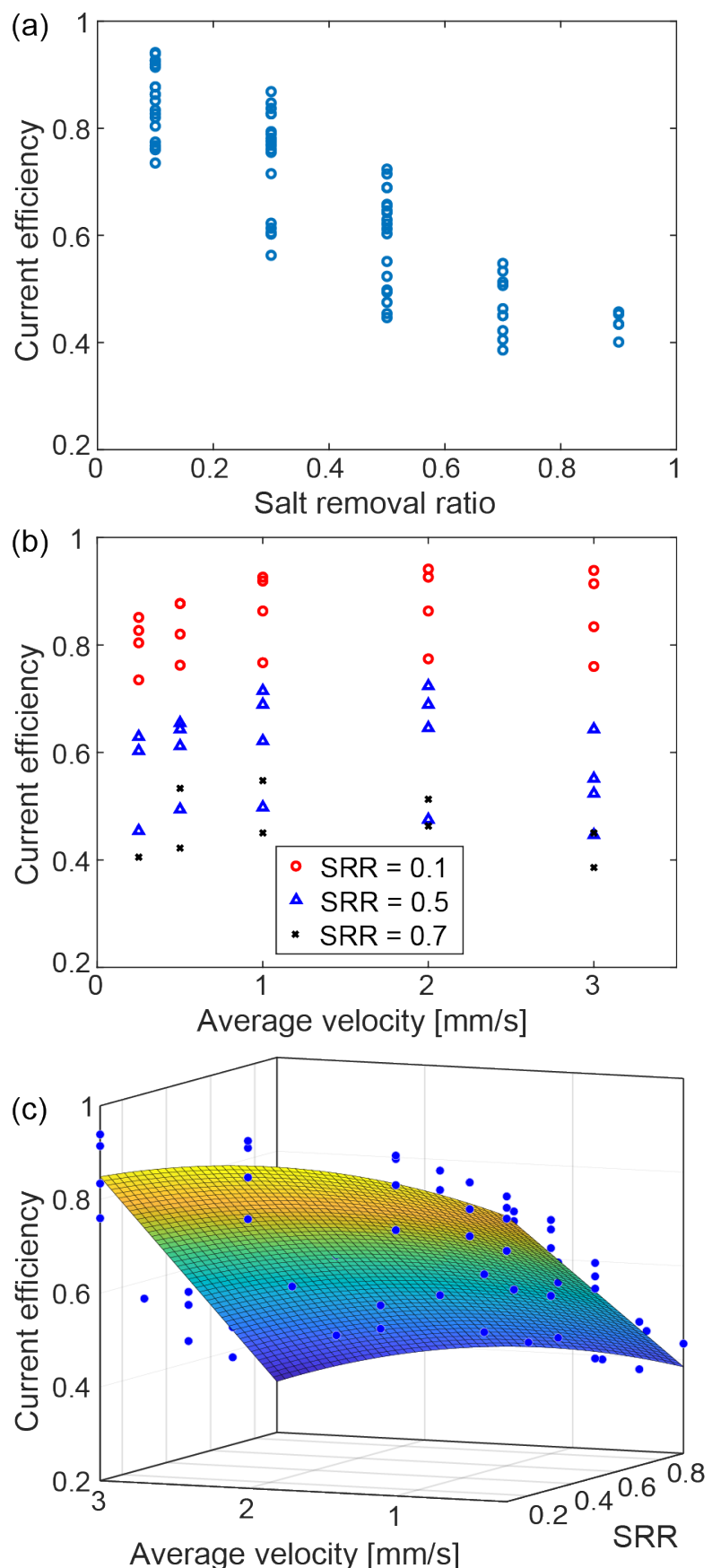

Average velocity $[\mathrm{mm} / \mathrm{s}$ ]

753 Fig. 4 Current efficiency as a function of salt removal ratio (SRR) and average flow velocity. The experimental data were generated with a fixed device configuration. (a) Current efficiency as a function of SRR, for a range of feed salinity and flow velocity, follows a linear relation. (b) Current efficiency as a function of average flow velocity, for a range of SRR and flow velocity, follows a quadratic relation. Only the data for $10 \%, 50 \%$, and $70 \%$ were plotted to easily show the quadratic trend. (c) Current efficiency was plotted as a function of SRR and flow velocity, and the data was fitted to a polynomial surface. 


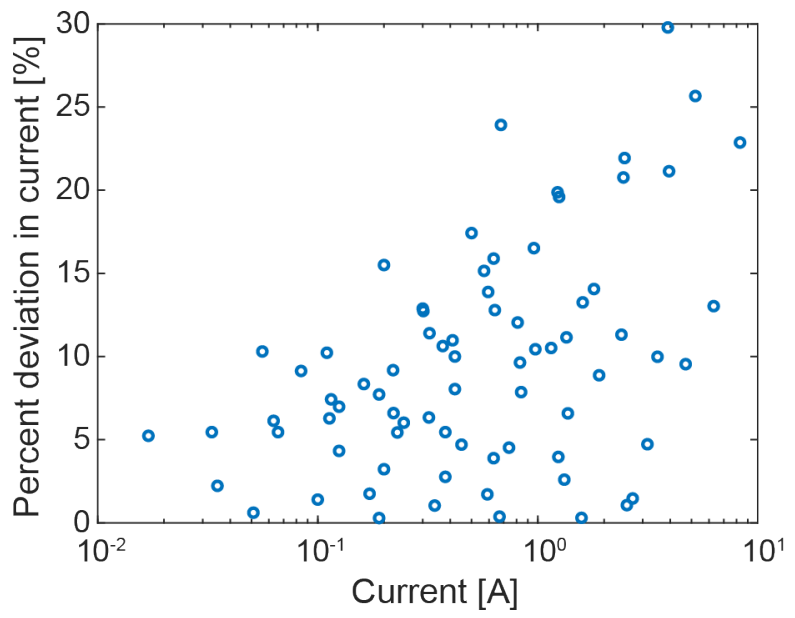

Current $[A]$

761 Fig. 5 The estimated current using the CE fitting model for given feed salinity, SRR, and flow 762 velocity. The (absolute) percent deviation of the estimated current from the measured current was 763 plotted. 
(a)
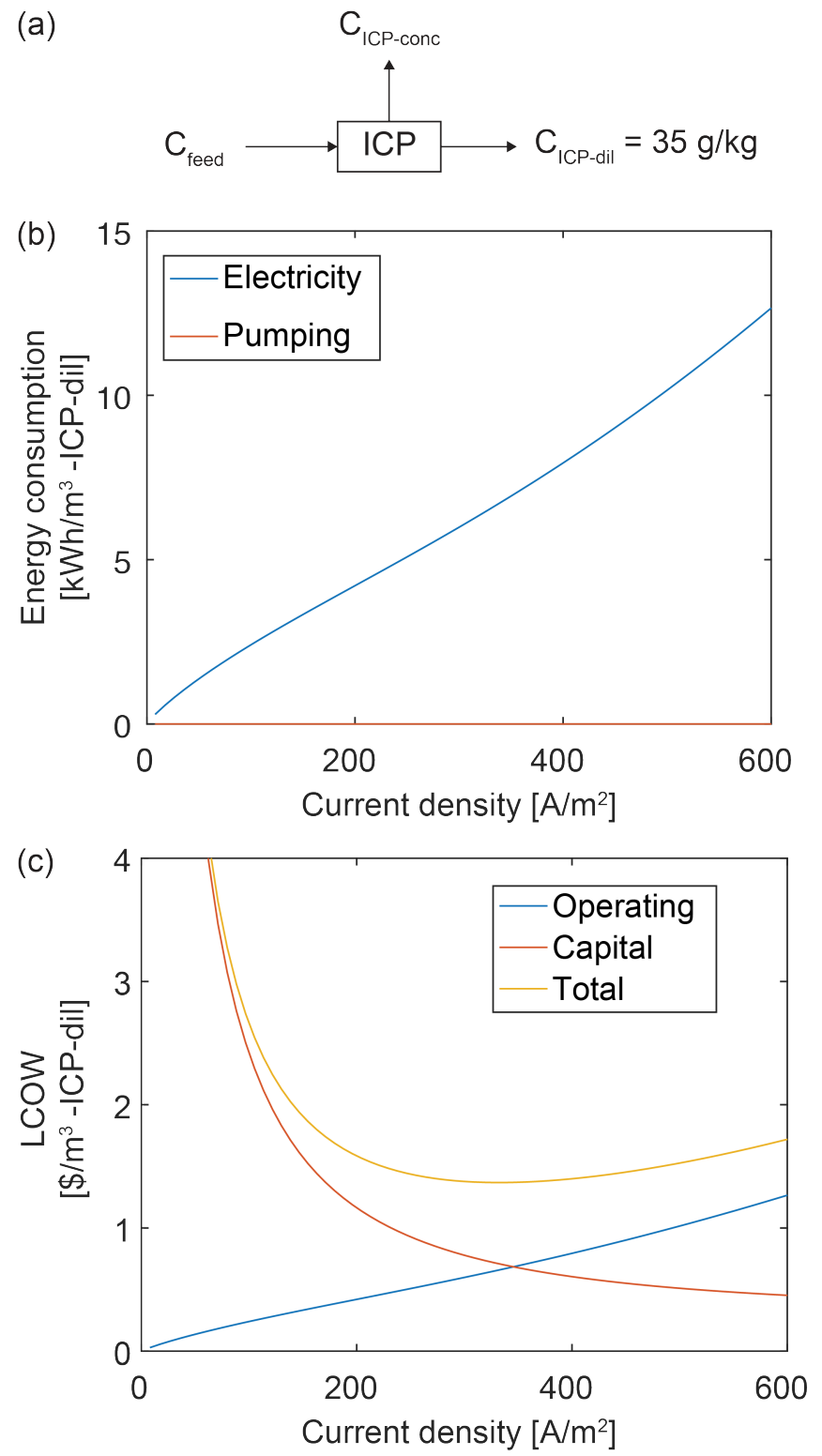

764

Fig. 6 Water cost optimization for partial desalination from feed salinity of $50 \mathrm{~g} / \mathrm{kg}$ to diluate salinity of $35 \mathrm{~g} / \mathrm{kg}$. Recovery ratio $(\mathrm{RR})=0.5$. (a) Schematic of ICP partial desalination used in Fig. 1(a). The diluate salinity is fixed to $35 \mathrm{~g} / \mathrm{kg}$. (b) Electrical and pumping energy as a function of current. (c) LCOW as a function of current. Total cost is the sum of operating (electricity) cost and capital cost. All costs are expressed as U.S. dollar per diluate volume $\left(\mathrm{m}^{3}\right)$. 

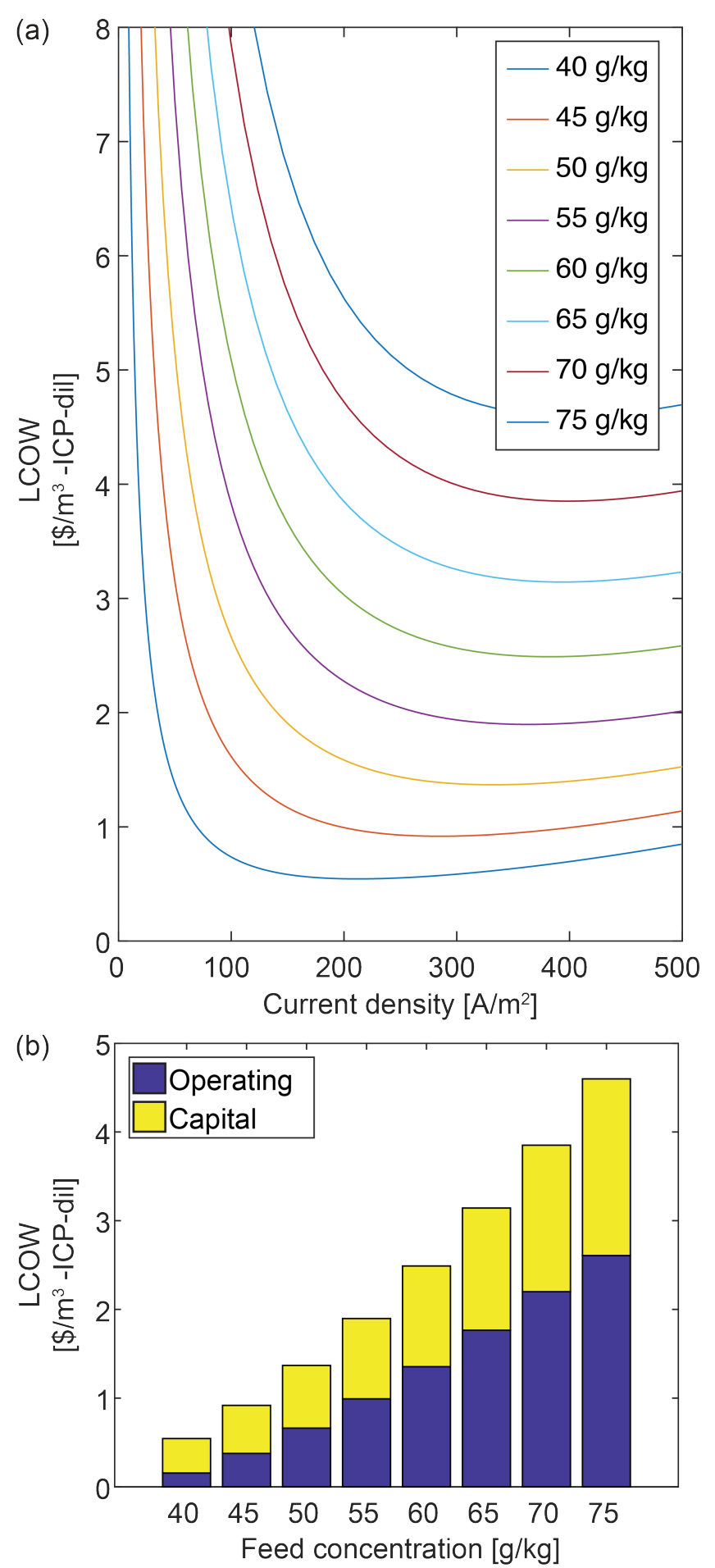

Fig. 7 Water cost optimization for partial desalination for various feed salinity. Diluate salinity is fixed to $35 \mathrm{~g} / \mathrm{kg}$ (seawater level). $\mathrm{RR}=0.5$. Total cost is the sum of electricity cost and capital cost. All costs are expressed as U.S. dollar per diluate volume $\left(\mathrm{m}^{3}\right)$ (a) LCOW as a function of current for various feed salinity. (b) Optimal LCOW for a range of feed salinity, broken down into 775 contribution from operating and capital costs. 

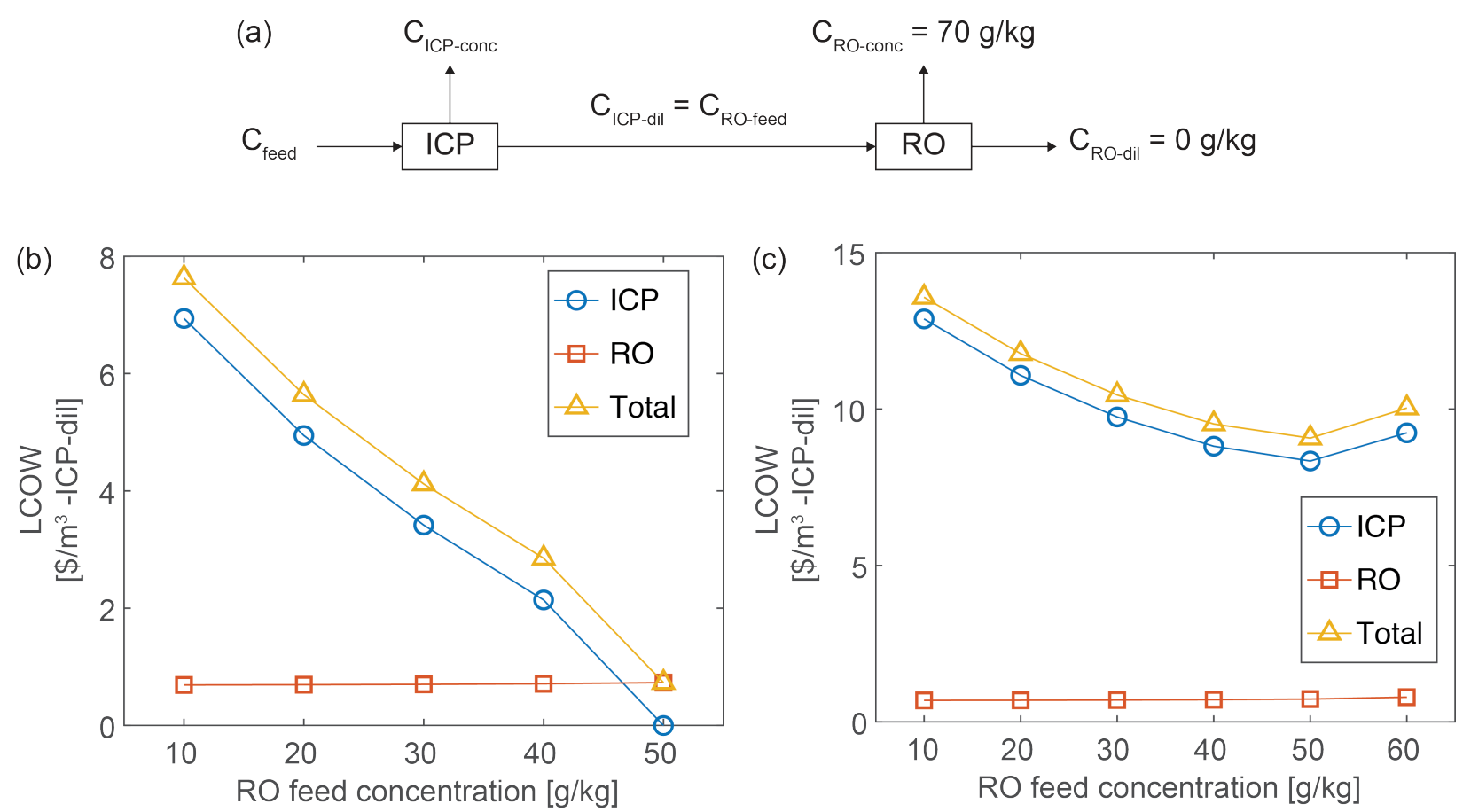

Fig. 8 ICP-RO cost analysis. (a) Schematic diagram of the ICP-RO hybrid. ICP desalination was performed on an ICP feed salinity of $50 \mathrm{~g} / \mathrm{kg}$ (b) and $75 \mathrm{~g} / \mathrm{kg}$ (c), and the ICP diluate stream was taken for complete desalination by RO. Hence, the RO feed concentration is equal to the diluate concentration of ICP. In all cases, the recovery in ICP was 50\%, and the recovery of RO was varied to give a fixed concentrate stream concentration of $70 \mathrm{~g} / \mathrm{kg}$. When the RO feed concentration equals the overall feed salinity, the water cost is for a RO-only process, whose recovery is double of the ICP-RO hybrid. 

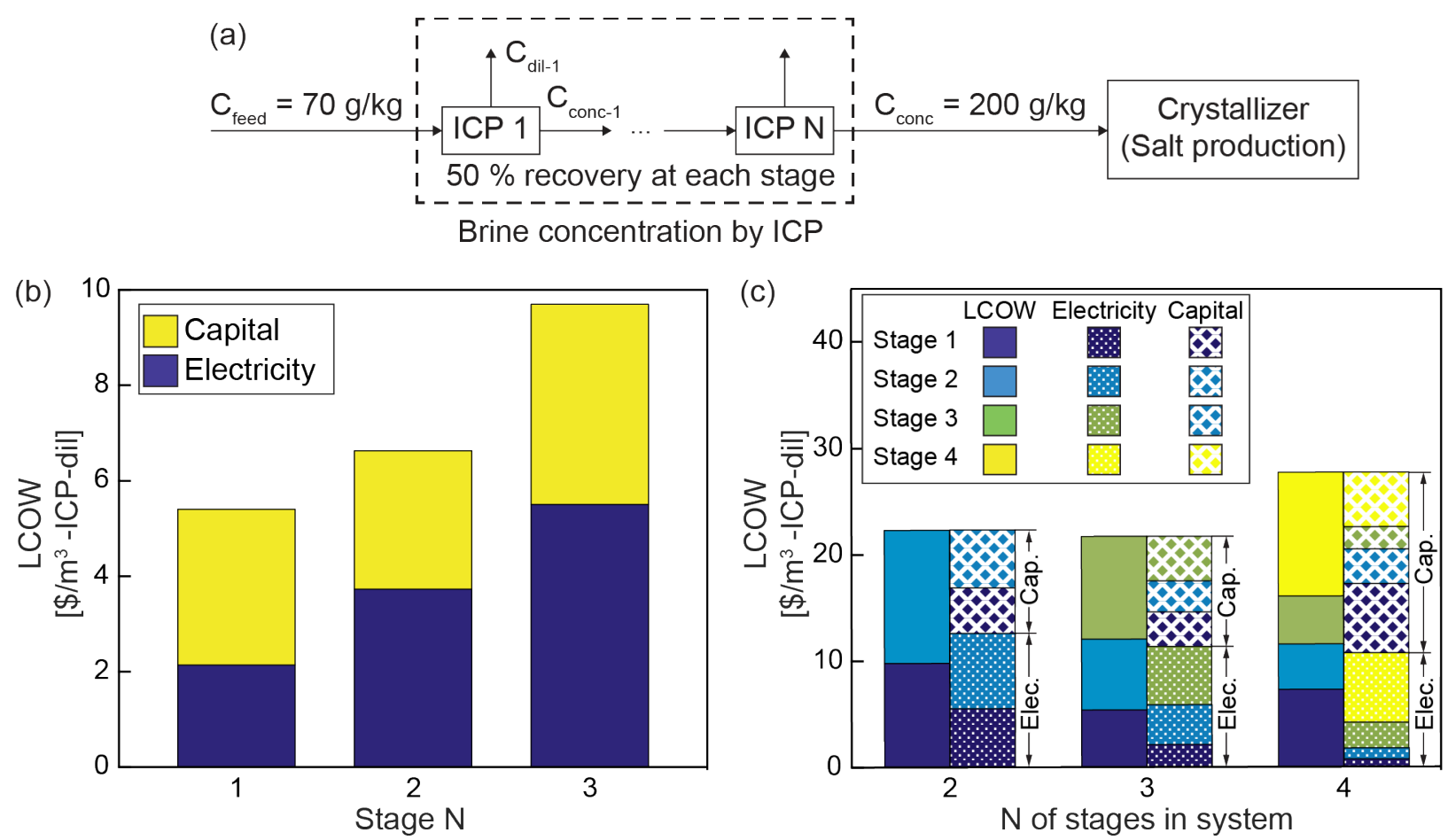

Fig. 9 ICP desalination for brine concentration. (a) Schematic diagram of multi-stage ICP desalination for brine concentration. $\mathrm{N}$ is the number of stages. In all cases, the salt removal ratios for all stages in a system were about the same. (b) Water cost for 3-stage system, broken down by stage. (c) Water cost for systems with various stage numbers. 

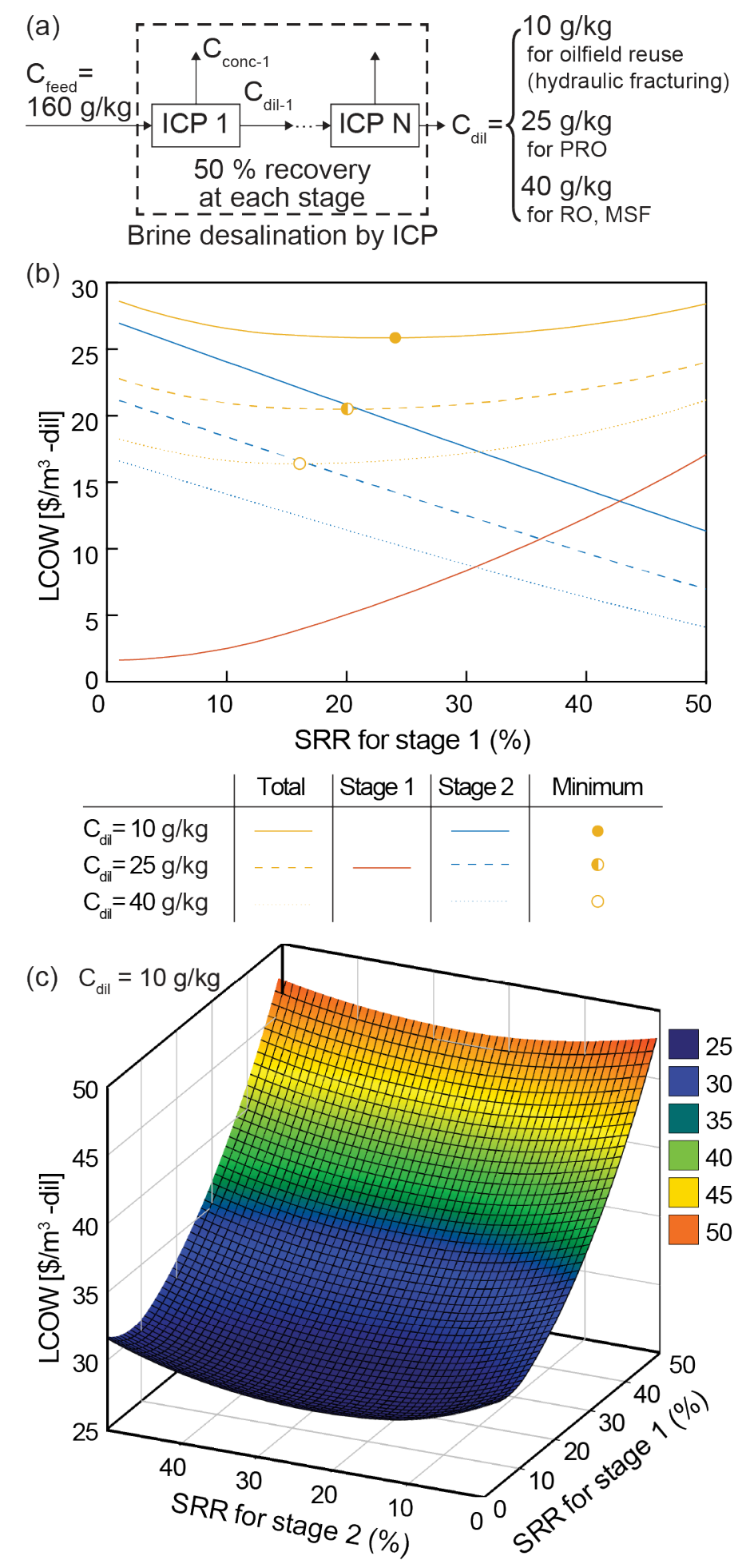

790 Fig. 10 ICP desalination for brine desalination from oil industry. (a) Schematic diagram of multi791 stage ICP desalination for salt removal. $\mathrm{N}$ is the number of stages. Water cost variations for (b) 2792 stage system with respect to SRR change at stage 1 and (c) 3-stage system with respect to both 793 SRR change at stage 1 and stage 2. 

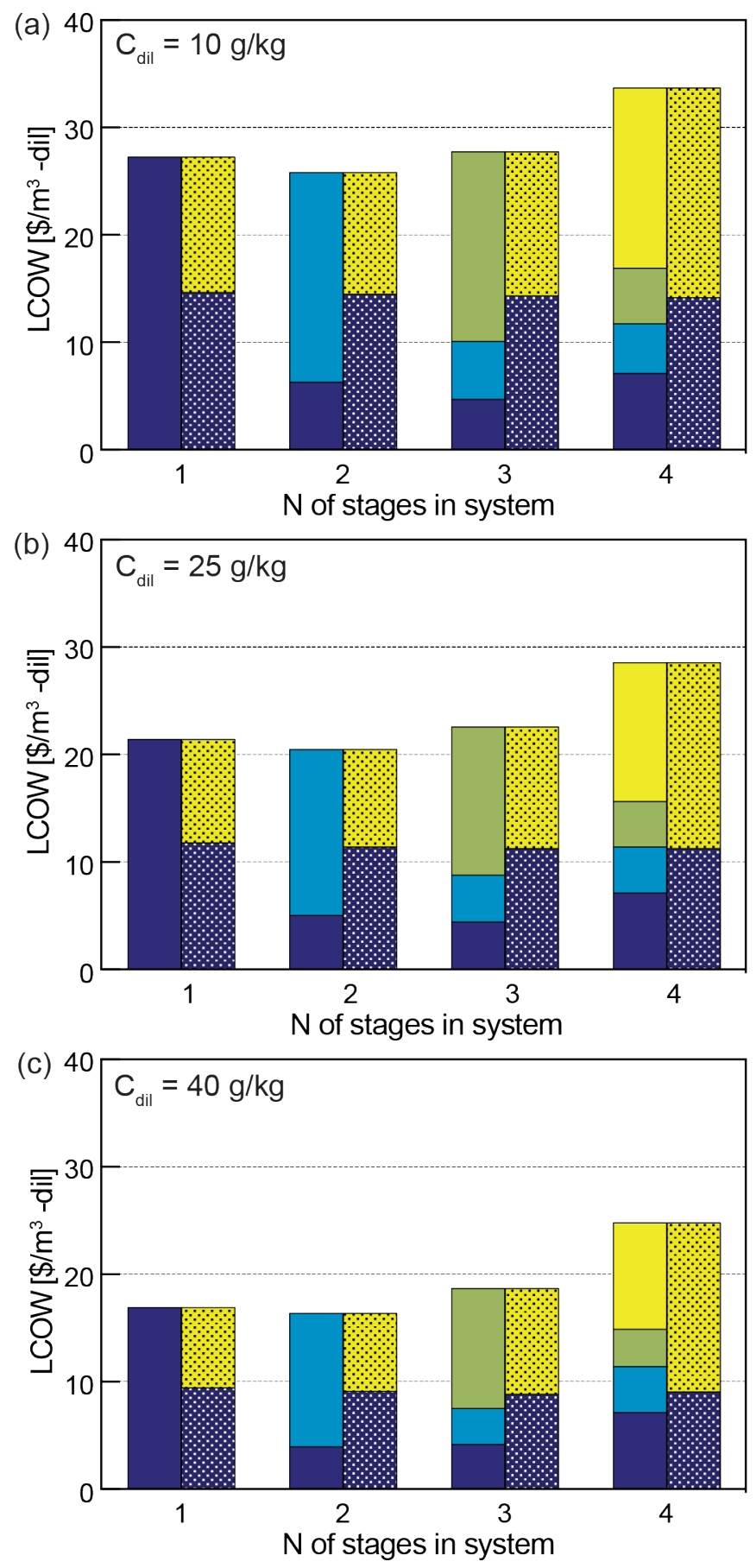

795 Fig. 11 Minimum brine treatment cost from oil industry with the ICP desalination system. Various 796 stage numbers, from 1 to 4 , are evaluated to achieve fixed final diluate concentrations, (a) 10, (b) 79725 and (c) $40 \mathrm{~g} / \mathrm{kg}$. 